Illinois State University

ISU ReD: Research and eData

Theses and Dissertations

3-14-2016

\title{
Virginity And Intellectual Construction: The Function Of Virginity Within The Early English Novel
}

Jayna Morgan Leipart Guttilla

Illinois State University, gjleipa@ilstu.edu

Follow this and additional works at: https://ir.library.illinoisstate.edu/etd

Part of the English Language and Literature Commons

\section{Recommended Citation}

Leipart Guttilla, Jayna Morgan, "Virginity And Intellectual Construction: The Function Of Virginity Within The Early English Novel" (2016). Theses and Dissertations. 517.

https://ir.library.illinoisstate.edu/etd/517

This Thesis is brought to you for free and open access by ISU ReD: Research and eData. It has been accepted for inclusion in Theses and Dissertations by an authorized administrator of ISU ReD: Research and eData. For more information, please contact ISUReD@ilstu.edu. 


\title{
VIRGINITY AND INTELLECTUAL CONSTRUCTION: THE FUNCTION OF VIRGINITY WITHIN THE EARLY ENGLISH NOVEL
}

\author{
Jayna M. Leipart Guttilla
}

\section{Pages}

This project situates the state of virginity as both a narrative and mode of behavior within Samuel Richardson's novel Pamela. By challenging the supposition that feminine virginity in eighteenth-century novels is presented as both an intellectual and physical disability, this thesis allows for a reconsideration of how virginity functions in the early novel. I place virginity in three distinct and yet simultaneous modes of thinking that contributed to the conflicting and contradictory images of women that were available to purchase in print: virginity as moral intelligence and form of resistance; virginity as an intellectual disability, and the loss of virginity as intellectually enabling. These three modes of thinking and, in turn, behavior, allow for the state and site of virginity to be bound intrinsically with the textual production and social constructions that were used during the eighteenth century. The ways in which women were portrayed and constructed in narratives such as Pamela signified that textual inscription was not merely being enacted upon paper materials, but rather on women's bodies themselves. 
KEYWORDS: Virginity, Pamela, Moral Intelligence, Samuel Richardson, Anti-Pamela, Fantomina. 
VIRGINITY AND INTELLECTUAL CONSTRUCTION:

THE FUNCTION OF VIRGINITY WITHIN

THE EARLY ENGLISH NOVEL

JAYNA M. LEIPART GUTTILLA

A Thesis Submitted in Partial Fulfillment of the Requirements for the Degree of MASTER OF ARTS

Department of English

ILLINOIS STATE UNIVERSITY

2016 
(C) 2016 Jayna M. Leipart Guttilla 
VIRGINITY AND INTELLECTUAL CONSTRUCTION:

THE FUNCTION OF VIRGINITY WITHIN

THE EARLY ENGLISH NOVEL

JAYNA M. LEIPART GUTTILLA

COMMITTEE MEMBERS:

Katherine Ellison, Chair

Tara L. Lyons 


\section{ACKNOWLEDGMENTS}

The writer wishes to thank Dr. Katherine Ellison and Dr. Tara Lyons for their encouragement and insight.

J. M. L. G. 


\section{CONTENTS}

Page

ACKNOWLEDGMENTS

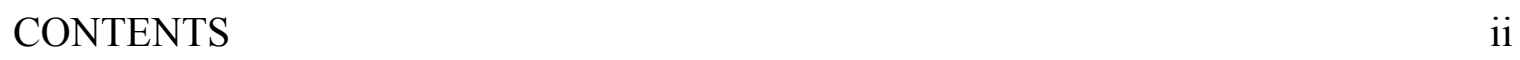

CHAPTER

I. INTRODUCTION 1

II. VIRGINITY AS MORAL INTELLIGENCE IN
SAMUEL RICHARDSON'S PAMELA

III. VIRGINITY AS INTELLECTUAL DISABILITY 34

IV. LOSS OF VIRGINITY AS INTELLECTUALLY ENNABLING 51

$\begin{array}{ll}\text { REFERENCES } & 74\end{array}$ 


\section{CHAPTER I}

\section{INTRODUCTION}

This project is an attempt to revisit virginity as both a narrative and mode of behavior during the eighteenth century and in Samuel Richardson's novel Pamela, with acknowledgement of new work in cognitive studies and the history of intelligence that allow for a rethinking of how virginity functions in the early novel. I am interested in locating virginity in three distinct and yet simultaneous modes of thinking that contributed to the conflicting and contradictory images of women that were available to purchase in print: virginity as moral intelligence and form of resistance; virginity as an intellectual disability; and the loss of virginity as intellectually enabling. These three modes of thinking and, in turn, behavior, allow for the state and site of virginity to be bound intrinsically with the textual production and social constructions that were used during the eighteenth century. The ways in which women were portrayed and constructed in narratives such as Pamela signified that textual inscription was not merely being enacted upon paper materials, but rather on women's bodies themselves.

Chapter 2 centers upon Richardson's Pamela and how the eponymous heroine employs the state of her virginity as the site of her resistance to sexual assault and psychological abuse from her captor, Mr. B. Next, chapter 3 offers a reverse insight where I seek to find instances in which Pamela's virginity is portrayed as the source for 
her inferior intelligence, as virginity is primarily distinguishable within the early novel as a state of maidenhood (and all of its associated synonyms: uncorrupted, demure, etc.) rather than a masculine function. Finally, in chapter 4, I highlight instances within the novels Anti-Pamela and Fantomina, which were contemporaneous to Pamela, where women refashioned the construct of virginity into an authoritative act of sexual emancipation.

My purpose in this project is to challenge the supposition that virginity in eighteenth-century novels is both an intellectual and physical disability and the moral foundation upon which women centered their behavior. Richardson, in particular, was popularly and satirically known as a moralizing novelist who with each passing edition of Pamela sought to engender Pamela and her captor Mr. B. as characters who are essentialized, at times belatedly and repentantly, as moral beings. However, I argue that with each edition and the substantial changes made to them, Richardson was not attempting to essentialize feminine moral behavior but rather stabilize moral behavior through radical interactions between his characters. Indeed, Tom Keymer writes upon Richardson's extended editorial alterations in his article "Assorted Versions of Assaulted Virgins; or Textual Instability and Teaching:

Having published [Pamela] in 1740, Richardson consistently underestimated demand for his best-selling work, which was in its sixth edition with eighteen months, with further editions to follow in 1746 and $1754 \ldots$ With over 8,400 substantive changes, ranging in size from substitutions of single words to whole pages cut or added, the 1801 edition brings to its belated climax a process of revision in which each published version differs markedly from the last, and often 
extensively so, even when separated from its predecessor by just a few weeks. There are 841 textual changes in the second edition; 950 in the fifth; 663 in the octavo sixth, including large additions (25).

Such marked alterations in a period of sixty years is remarkable and perhaps contributed to the instability and variance in reader's responses to the novel. Pamela, to a point, is a novel which inverts seemingly stable social infrastructures and calls attentions to the limitations of social constructs: woman against man, lower class against higher class, established hierarchies against the lone individual (Doody, 109). One can certainly argue that Richardson inscribed Pamela as a hyperbolically moral being, but he did so in ways that went against the established and normalized codes of conduct. To call Richardson a radical is not accurate, as he reveled (and made his fortune) in his connections to the establishment and the aristocracy. However, one could add the modifier that Richardson sought to underline his seeming radicalism with a solid foundation of morality and thus created a novel that infuriated, delighted, and baffled readers and critics alike.

Like the novel itself, Pamela's virgin state was at once deplored, satirized, and lauded by readers. As Corrine Harol writes, this varying degree of reaction was at the heart of the debate over feminine embodied intelligence: "The rapid and prolific accretion of satires, defenses, and debates that followed the publication of Pamela depend for their effect on the instability of the evidence of Pamela's virtue; that is, they exploit the idea that virtue, like virginity can be faked" (Harol, 199). Harol is correct in pointing to the duality that surrounds Pamela and its creator. Richardson's continuous and manic production of the Pamela editions is clearly his attempt to control the response to the novel and its heroine. However, through his repeated and didactic illustrations of 
Pamela's high moral intelligence vis-à-vis her embodied virtue, Richardson has inadvertently contributed to the very traditional notion that women are always either unequivocally moral or entirely lascivious. So in many ways, Richardson's radical moralism is undercut by his entirely didactic treatment of both women and men's dichotomous perceptions of women.

Both in terms of gender construction and marriage, women were often and repeatedly instructed to recognize their bodies through the myopically masculine sexual marketplace. Women learned how to navigate such treacherous terrains by seeming virtuous or performing virtue. This virtue that a woman embodied could be reduced simply to her sexual activity or lack thereof: was she a virgin or was she a whore? Was she chaste or ruined? The anxiety surrounding a woman's status as a virgin and moreover her ability to engender a chaste rather than illicit desire in men is rooted both in the anxiety of "proper" lineage and the ironic knowledge of such contradictory idealizations. Such generalizations, now and during the eighteenth century were, and are, irreducibly dangerous and yet they persisted in ways that constructed women into dichotomous personas rather than fully formed individuals.

Surely, Richardson was not consciously or purposely concerned with the social constructions of feminine bodies in masculine discourses. However, in this project I will argue that he was concerned with the effect of moral behavior and that he constructed Pamela as the embodiment of right and rational morality. The divergence between Richardson's seeming purpose and his reader's varied reactions to the novel is important to note, as I view Richardson as having a foundational moral understanding that is derived from his Puritan beliefs (a much more thorough discussion of Richardson and his 
Puritan beliefs is undertaken in chapter 2), and as such, distinct from the general reading and theatre going public. Puritan belief was structured around the belief that man had to look inward to find salvation, and as C.G. Wolff's book Samuel Richardson and the Eighteenth Century Puritan Character articulates, Richardson's novels often explore "the three ego-ideals which dominated the Puritan's image of himself, that is, 'Puritan as Selfexaminer, Puritan as Virtuous Example, and Puritan as Saint" (Harvey, 38). Richardson's use of the epistolary form in Pamela is remarkable in that he not only situates a woman as the central moral figure in the novel, but he also provides the reader access to her inner dialogue; in other words, the reader is viewing Pamela's self-examination, her version of events in which she has behaved in a virtuous manner, and the vindication, by way of her moral instruction and marriage to Mr. B., of her status as saint.

All of the above is to argue not that Pamela herself is a Puritan, but rather that she is a model of Puritan behavior, a mode in which I think it is safe to argue Richardson himself was steeped within and sought to promote. In History of Intelligence, C.F. Goodey argues that during the transition in England from the early modern to the modern period a period of soft rationalization was occurring:

The softer side of feminine values could be of considerable use to male power. While woman's rightful place was in the private sphere of home, private men were a potential threat. Private male reasoning might lead to heresy or opposition. [In Tudor times] testostrionic men were to be kept away from the nursery because their private minds and self-assertive behaviors might set a bad example to the young, fostering oppositional defiant disorder or an unreasoning disdain for reasons of state. The young had to be socialized into obedience to its head...The 
Puritans who grew in political strength over the next generation would have been the first to learn to police themselves in this way. Their rejections of the honour clans' way of bidding for status, in favor of an internal religious grace and regeneration or "new man," was their rejection of machismo for a more feminine quality that would eventually enable Puritan elites, male of course, to manage more softly and delicately the levers of power (98).

This model of soft moral management can surely be identified in Richardson's Pamela and Clarissa, where he sought to overcome morality in its affective form and replace it with example of women who were purely moral and purely good.

In chapter 2, I argue that Pamela's purpose or thesis is to demonstrate to the reading audience how "true" morality is tested through the function of a feminine embodied moral intelligence. In chapter 3, my argument shifts toward the notion that women were perceived as irrational beings whose feminine intellectual disability lies in their essential "affective-ness" or performative nature. In other words, women are styled as ornaments and men as rational beings. In her discussion of Ruth Bloch's work, Tassie Gwilliam writes:

The change in sex roles in terms of a movement from an emphasis on 'difference in degree' in the sixteenth and seventeenth centuries, to a promotion of 'difference in kind' in the eighteenth and nineteenth centuries. In the eighteenth century, [Bloch] perceives an increasing separation of male from female imagery and activities, as well as a stronger contrast between male 'rational' and female 'affective styles.' These broad alterations in roles to some degree penetrate all 
levels of discourse, but at times the apparent transformation seems simply to reorient, rather than diminish, anxieties about women's deceitful display. (16). This transition from a difference in degree to a difference in kind must be linked to narratives such as Pamela by Samuel Richardson that sought to figure the ideal woman as one who must be at once constrained, contained and whole until a time wherein she consents, as Rousseau so gallantly phrases it, to the domination of both her mind and body, in terms that were at once intellectual and sexual. She has to prove, as it were, that she needs governance — and Richardson's narrative describes at length how Pamela's naiveté constrained her ability to navigate through the snares of Mr. B's lair-and moreover that she was able to satisfy a man's desire in a thoroughly licit manner prior to a sexual consummation. So, the virginal female must seemingly go through the rigors of first, exciting a man's illicit desires; second, displaying an inability to function without a masculine protector and, finally, consenting to be overtaken by that said masculine protector so that her so-called feeble body and mind could be safeguarded from further damage.

Gwilliam connects the transition to a difference in kind to the rise of the middle class during the eighteenth century and locates "this ideological change ... to women's presumed loss of productive work and an increase in leisure under capitalism, and thus to the new status of women as 'consumers rather than contributors to the household economy" (16). This purported loss of purpose is highly visible in a text like Eliza Haywood's Anti-Pamela as the protagonist Syrena Tricksy, who is constructed as the essentialized Other to the figure of Pamela, is able to exchange capital in a sexual economy, an economy for which Pamela is absolutely forbidden to participate in. Syrena, 
while ultimately tamed by Haywood's refusal to allow her to profit by the commerce of her body, is tenacious if not highly functional. Her status as the anti-Pamela provides her with an ability to participate in the public arena, and as such she is en-abled while Pamela is thoroughly dis-abled.

In $A$ Vindication of the Rights of Woman, Mary Wollstonecraft points to an illicit and wholly unreasonable trend occurring in eighteenth-century intellectual discourse wherein men were attempting to establish what constituted goodness through the parameters of morality and intelligence. Men who were capable of moral behavior were also thought to be intelligent in that they were able to simply distinguish "good" from "bad." These terms, however, are expressly subjective and informed by a gendered hierarchy that presupposes the masculine as that which is moral and intelligent and therefore reasonable. In almost all of the definitions that exist of morality, reason, and intelligence, the figure of the woman simply does not exist. She is an anathema to the staid figure of the Man. It is He who becomes a pillar for moral and just behavior. It is $\mathrm{He}$ who displays a natural intelligence that is stationed above all others and seated below the figurehead of God. And finally, it is He who is fully cognizant and able to use his faculties of reason to navigate both himself and his followers throughout the unnaturally evil world. The figure of the woman is at once always essentially sinful, wholly animalistic in her intellectual capabilities, and impossibly unreasonable. While surely there were instances of moral women and women who possessed seemingly unnatural intellectual capabilities, they could neither be wholly moral or entirely intelligent nor employ the two former abilities in ways that permitted them to be or exhibit reasonable behavior. 
Wollstonecraft points to Rousseau's figuration of women as particularly insidious and debasing:

Women are, therefore, to be considered either as moral beings, or so weak that they must be entirely subjected to the superior faculties of men. Rousseau declares that a woman should never, for a moment, feel herself independent, that she should be governed by fear to exercise her natural cunning, and made a coquettish slave in order to render her a more alluring object of desire, a sweeter companion to man, whenever he chooses to relax himself. (25)

If women were thought to be incapable of reason and therefore also lack the essential intellect or understanding to function in public society, why would Rousseau point to fear as the thing from which women should govern themselves? Fear is based upon a hierarchy of power, a structure that seeks to blind those who feel burdened by the emotionality of fear and thus will be rendered mute by the anxiety of exposure. Furthermore, fear, from the one who suffers from this oppressive state, seemingly is embedded in the knowledge of something and so is clearly a learned, rather than innate, product of cultural practice. Rousseau writes:

The strongest should be master in appearance, and be dependent in fact on the weakest; and that not from any frivolous practice of gallantry or vanity of protectorship, but from an invariable law of nature, which, furnishing woman with a greater facility to excite desires than she has given man to satisfy them, makes the latter dependent on the good pleasure of the former, and compels him to endeavor to please in his turn, in order to obtain her consent that he should be strongest. (80). 
Rousseau establishes the natural cunning of woman as her essential fault and translates women's physical disability in comparison to men's greater ability as a fundamental lack and moreover as proof that women's behavior needs to be governed. He complicates this notion by insisting that men must be "dependent" upon women simply because they embody the very thing that men desire, but his assertion becomes manifestly unreasonable when he argues that men must obtain women's consent to be the "strongest" and thereafter their master. Wollstonecraft counters this statement by exhorting readers to pay attention to the force by which men seek to overpower women: Formed to live with such an imperfect being as man, they ought to learn from the exercise of their faculties the necessity of forbearance; but all the sacred rights of humanity are violated by insisting on blind obedience; or, the most sacred rights belong only to man...The being who patiently endures injustice, and silently bears insults, will soon become unjust, or unable to discern right from wrong. (85) If women, as Rousseau would have it, were neither capable of cogito or the awareness of and ability to reason, nor possess the physical strength to overcome men and so must be rendered as mere objects of delight for their masculine companions, how indeed were they able to function within a site of affect, always in a mode of performance? How does one's ability to reason and one's perceptible understanding of cultural production and performance relate to the construction of moral idealizations? If women, as Rousseau clearly argues, are at once lacking in their physical abilities, unable to cogently reason or possess a complex understanding of public life, and are innately cunning in ways that men find desirous, how are women then able to navigate within these bifurcated constructions? Clearly, Rousseau was speaking about women who were not participants 
in a sexual economy, but rather only to women who he viewed as fully embodying the morality that was inscribed onto them by men — women like Pamela. Women who were defined as virginal (in essence, innocent of sexuality) and who had yet reached a point in which they were capable of reason and an intellectual understanding by way of their seeming dependence upon a masculine authority, were rendered dis-abled precisely because of their lack of participation within the sexual economy.

Virginity can be identified as an intellectual disability because narratives such as Pamela and the treatises written by Rousseau insisted that unlike men, women were neither divinely nor innately equipped with the faculties of reason and as such needed protection from themselves. Seen through the guise of an enacted protector-ship, virginity becomes a form of self-regulation and thus internalized into an embodied morality. This protracted form of masculine governance is enforced both physically and textually by men who sought to disable women by aligning them with figures who were more child than adult. The anxiety regarding a women's virginity was directly tied to man's inability to contain women's sexualities, and this anxiety then produced narratives that foregrounded women's inherent intellectual inability.

This thesis, which is concerned mainly with Pamela (with short sections on AntiPamela and Fantomina), is an effort to reclaim the discourse surrounding virginity within the eighteenth century and demonstrate how models of virginity could serve to both elevate and diminish women in their cultural constructions. Virginity often acted as a marker of a woman's virtue, but here I argue that virginity in Pamela serves as a model for a woman's moral intelligence and form of resistance. Likewise, virginity was often seen as an intellectual disability, similar to the notion of the tabula rasa, which ennobled 
men to authorize power over women. Finally, I seek to address the loss of virginity as intellectually enabling with examples of women who employed the state of their virginity as moral intelligence where women sought to remove the construct of virginity as an authoritative act of sexual emancipation. 


\section{CHAPTER II}

\section{VIRGINITY AS MORAL INTELLIGENCE IN SAMUEL RICHARDSON'S PAMELA}

The subtitle of Samuel Richardson novel Pamela_Virtue Rewarded —is a signal to the reader that what lies within the pages of the text is the story of a girl whose moral righteousness is scrutinized and authenticated. Pamela's story is fundamentally concerned with the defeat of immoral and licentious behavior and how seemingly corruptible youths overcome temptation in order to become exemplars of the "right" moral code. Pamela, however, is the embodied representative of Richardson's idealized notion of moral behavior and uses the state of her virginity as the compass for her moral and virtuous behavior. With access to Pamela's letters and journal, the reader is shown how the embattled heroine is able to overcome the sexual and psychological abuse from her captor, Mr. B., by the application of what I designate as her "moral intelligence." The preservation and defense of morality is Richardson's primary concern within Pamela. From the beginning of the novel where Pamela's father instructs her to "stand upon your Guard; and, if you find the least Attempt made upon your Virtue, be sure you leave every thing behind you" (14) to her marriage to Mr. B. when she confronts the detractors to their marriage, Pamela is operating within a hierarchical understanding of morality and 
discipline wherein she cannot, at any cost, abandon the directives of her guardian who, following the normative spectrum of authority that existed for a young woman within the Eighteenth century, is first her father and then her husband.

My definition and use of the term "moral intelligence" extends beyond the standard psycho-social denotation, which is generally defined as the possession of an explicit understanding and knowledge of a particular system of values and principles that determine certain actions as right and wrong or good and bad. This general definition is appropriate when discussing a wide and varied population, but it is not productive when one attempts to apply it to a specific context. As such, I am defining "moral intelligence" as not simply employing a virtuous or ethical perspective or even as the ability to acquire and apply knowledge for the greater good. Rather, my reading demonstrates that moral intelligence must be understood as a person's ability to at once embody an expressly felt knowledge in their person and perform their righteously held understanding in a manner that affects not only the use of their body as a reaction against their lived circumstances, such as Pamela's fainting fits when Mr. B. attempts to rape her, but also how others perceive and make use of the feminine body. Liz Bellamy argues in Commerce, Morality and the Eighteenth Century Novel, that the early "...novel drew on diverse and disparate forms of popular literature. Each of them presented a particular vision of the economic and social structure, and tensions existed between those which emphasize a code of morality based on the negation of materialism, and those which celebrated economic and individual progress” (72). In Pamela Samuel Richardson uses both a particular code of morality that is manifested within Pamela and the economic triumph of the individual 
through her exemplary moral behavior. However, Richardson's fixed and particular concern with his character's moral and religious self-examinations was in no way an unusual point of interest during the seventeenth and eighteenth centuries but rather it is his attention to both, as Bellamy argues above and as I show below, the negation of materialism and the rise of the individual that is particularly subversive.

What was Richardson seeking through his creation of Pamela? As a printer and a searcher of knowledge in the age of Enlightenment who suffered many great personal losses - the deaths of his first wife, several children, as well as his father, brother and many friends—, one could imagine that he saw a life guided by moral principles as a consolation and reflection of bereavement. His inner life is one that remains ambiguous for scholars, as questions surrounding his faith (was he a Calvinist or a Puritan?) and his scholarly pursuits (A reader of Locke's Essay Concerning Human Understanding or no?) are ones that can only be resolved within the texts of his novels. Certainly, Locke's Essay Concerning Human Understanding provide a window through which Richardson could both question and clarify his epistemological perspective (385 DLB). In his 1689 Essay, Locke describes in the "Epistle to the Reader" his determined search for insight into human knowledge and its operations:

he who has raised himself above the alms-basket, and, not content to live lazily on scraps of begged opinions, sets his own thoughts on work, to find and follow truth, will $[\ldots]$ not miss the hunter's satisfaction; every moment of his pursuit will reward his pains with some delight; and he will have reason to think his time not ill spent, even when he cannot much boast of any great acquisition" (v). 
While the above passage was written as a sort of apology to the reader, it is important to note that Locke pays acute attention to the importance of reading, writing, and the rewards of a tenacious search for truth and knowledge (pg. 15-23) not unlike Pamela's epistolary search for morality within the enclosure of Mr. B.'s estates. Pamela's seeming naïveté reshapes itself into an active intelligence framed by a dogged sense of morality when one compares her to Locke's "hunter." She has risen above the station of a mere servant, ostensibly by her Ladyship's kindness and gratitude, but she is unwilling to forfeit her own understanding of morality for "scraps of begged opinions" in the form of Mr. B.'s attentions.

Prior to the seventeenth and eighteenth centuries, virtue was intrinsically connected to one's social position, and the higher that position, the stronger the presumption that one's morality and therefore one's virtue was of a higher quality than those who were positioned within the lower classes. The reward, like Locke's hunter "who has raised himself above the alms-basket," for Pamela's insistent morality is the vehicle for her ascension to a higher class. This ascension, or the reward alluded to in Pamela's subtitle, Virtue Rewarded, marks a correction in Pamela's circumstances, as she is now positioned in a social category that better fits her morality. These class-based associations with morality and virtue began to change after the execution of Charles I in 1649 , when power and virtue were no longer synonymous descriptors of the aristocracy. David Morse contends that Pamela was Richardson's attempt to illustrate the illusion of virtue as a marker of an aristocratic sensibility, meanwhile calling attention to proper moral instruction: 
While virtue may be theoretically the birthright, mark, and goal of the gentleman, in practice self-control is all too often perceived as utterly alien to the aristocratic code. So if the well born child is to be well brought up Pamela recommends that the young aristocrat should be led to emulate the virtues of a companion from a lower social background. If he studies alongside the "child of some honest neighbor of but middling circumstances" who has given indications of his "natural promptitude, ingenious temper, obliging behavior and good manners," then emulation and rivalry in the pursuit of virtue should result. (115)

It must be stated that despite Richardson's desire to highlight the illusion of an innate aristocratic system of morals, the reward of Pamela's virtue is in fact her ascension to Mr. B.'s aristocratic level. In other words, Richardson is still reinforcing x. Moreover, what appears to be simply the act of a sound moral education for Pamela's children can in fact be seen as a sort of class-based eugenics program that seeks to promote class ascension vis-à-vis an innate system of morals rather than a desire to promote true and ethical equality among the differing classes. For instance, on the eve of Pamela's and Mr. B.'s wedding day, both Mr. Andrews, Pamela's father, and Mr. Williams, Mr. B.'s chaplain, offer recitations from the Bible in honor of the marriage. In what appears to be a ritualistic recitation of sermons given as guidance to the young couple are actually confirmation that only "true" virtue, or virtue in practice, is rewarded. Pamela prefaces her father's reading of the $23^{\text {rd }}$ Psalm with the qualifier: "And as I know he had learnt Psalmody formerly, in his Youth, and had constantly practiced it in private, at home, of Sunday Evenings, (as well as endeavour'd to teach it in the little School he so unsuccessfully set up, at the Beginning of his Misfortunes, before he took to hard 
Labour" (313). Mr. Williams then recites the $11^{\text {th }}$ chapter of Proverbs, verses 24, 25 :

"There is that scattereth, and yet increaseth; and there is that witholdeth more than is meet; but is tendeth to Poverty. The liberal soul shall be made fat: and he that watereth, shall also himself" (314). These two recitations unite to frame Pamela on the day of her ascension to a higher class with virtuous men who ultimately failed in their practice of it. Neither Mr. Andrews nor Mr. Williams were successful in their promotion of a virtuous and moral life: Mr. Andrews practiced his Psalmody in private and was wholly unsuccessful in his endeavor to build a Christian school; Mr. Williams ultimately failed because he could not properly instruct Mr. B. in how to live within a moral framework. The Biblical passages that they cite are essentially instructions for humility and generosity, ideals that no men within the novel employ. Rather, it is only Pamela who reaps the rewards of a virtuous life as it is she who publically renounced Mr. B.'s abuse, and it is she who persuaded Mr. B. to overcome his immoral ways. Richardson's idealistic promotion of moral instruction itself is based upon the illusion that morality is a positivist endeavor in which all moral actions are unquestionably good and immorality is blackened with evil intention.

Despite the fact that Morse is referring in the above passage to the second part of Pamela, which takes place after her marriage to Mr. B., he importantly highlights Pamela's desire to curtail the immoral behavior in her own aristocratic children and promote an equality of morals based upon empathy and emulation. On this account Pamela, Mr. B. and their subsequent family have been rewarded by Pamela's insistent, if not illusory, morality and are rewarded by their devotion to moral instruction rather than a devotion to class hierarchy. Pamela's devotion to moral instruction can be noted within 
the correspondence between herself and her parents as each letter represents documented proof that she has withstood Mr. B.'s attacks with her virtue unbroken. Likewise, Mr. B.'s reward for his belated incorporation of moral instruction is access to Pamela's virginal body and thereby legitimate reproduction of heirs. This reward, which reinforces the illusion that moral boundaries are imbedded within class hierarchies, provides men like Mr. B. with a system to behave immorally and then rectify such behavior by performing the same acts within socially sanctioned boundaries like marriage. In effect, Richardson's promotion of universal moral instruction over the inbred conviction that virtue is an inherently aristocratic sensibility falls apart with the attainment of Virtue Rewarded. Pamela and Mr. B. are constructed as representations of proper moral instruction and illustrate Richardson's hard-fought notion that morality crosses class boundaries, but they ultimately displace the illusion of virtue as a marker of an aristocratic sensibility when Pamela ascends to a higher class and Mr. B.'s immoral and illegitimate behaviors are corrected by their marriage. Richardson's attention to the illusion of an innate class-based system of morals collapses when Pamela and Mr. B. are rewarded with class ascension through moral behavior and the sustainment of morality within prescribed boundaries.

Richardson situates Pamela's seeming naïveté into an active intelligence framed by a tenacious sense of morality, not unlike Locke's "hunter." However, the perception of Pamela is always fractured or altered by the assumption that immorality and greed are the cause for one's desire of class ascension. Pamela is epistemologically unique in that she cannot comprehend immoral action or rather assumes that everyone has an essential moral foundation despite their obvious immoral actions. She is presented as an anomaly 
in almost every section of the book and is rendered incomprehensible by those she encounters. For instance, in an early encounter, Mr. B. lambasts Pamela as "your own Enemy. Your perverse Folly will be your Ruin!” (31). Pamela's overt and purposeful virtue does not match Mr. B.'s understanding of what he considers to be a woman under his employ and guardianship, that is a woman whose body should be made accessible to him. Mr. B. interprets Pamela's steadfast refusal to engage in his pursuit of her as "perverse" because as an aristocratic male who has no social, moral, or practical wisdom to guide him, he cannot practically understand why anyone would refuse his proposal. While this chastisement occurs prior to Mr. B.'s imprisonment of Pamela, he clearly does not regard her as being adamantly virtuous and more to the point, he repeatedly persists in referring to her in disparaging terms such as "artful," "Equivocator," "hussy," the list goes on. In other words, how can she be rewarded for what she considers righteous behavior when those surrounding her view her through a lens of utter disbelief? The concern and unease surrounding both the status of Pamela's virtue, vis-à-vis her physical virginity, and the desire to uncover a thread of immorality within Pamela's seeming incorruptible judgment, calls attention to the illusory nature of virtue gained through the physical construction of virginity.

Richardson's full title—Pamela: Or, Virtue Rewarded — bears witness to the interminable trials that the novel's protagonist must undergo prior to the aforementioned reward. Pamela in its most essential form is a didactic text, and Richardson is clearly concerned with Pamela illustrating to the reader how one undergoes, maintains, and finally prospers under proper moral instruction. As such, Pamela is surely the manifest embodiment of moral intelligence in that she is both fundamentally concerned with her 
body retaining its un-sexualized purity and implementing the protection of her virtue by all means necessary, despite threats against her moral sensibility and later the physical threat of rape.

Virtue should be distinct from virginity as virtue is an epistemological imperative that is akin to morality, whereas virginity is a state that a body is understood to be in and that for Pamela must be maintained as evidence of her virtue or virtuosity. Contesting a woman's virginity is difficult in that physical proof of an intact hymen often produces inconstant results, as well as marking the woman examined as incontrovertibly immoral. By contrast, the immateriality of virtue presents an opportunity for a writer like Richardson who is concerned with moral instruction to construct a character so hyperbolically virtuous that doubt and uncertainty concerning her actual virtuous state must follow. Corrine Harrol asserts that the novel's epistemological question concerning Pamela's virginity as a virtuous construct is the very thing that allows the novel to progress from a story of captivity and rape to something that we now recognize as a marriage plot. As the novel itself is centered on proof of virtue, the scientific methodology employed by Mr. B. is the trial for which Pamela must undergo in order to for the story to resolve itself with a conclusive marriage:

In its focus on Pamela as the narrator of her own story, the novel displaces epistemological anxiety from the male to the female. As an epistolary novel, Pamela circumvents the problem of the body by suggesting that it is women's words, not their bodies, that may escape male investigative methods. Moreover, Pamela positions the reader - rather than the women herself, a man who may be sexually interested in her, or a scientist — as the one with access to the most 
reliable evidence; as such, it creates a disinterested, nonscientific community that may debate Pamela's virginity and her virtue as "matters of fact." (135)

In order to understand Pamela as a virtue embodied, Richardson had to construct a series of trials to prove to the [male] reader that Pamela's virginity was not only evidence of her moral intelligence but also of her virtuous nature.

The primary concern of Pamela then, is to retain her seemingly coherent understanding of virtue as it has been defined within the framework of her un-sexualized body and resist all attempts to render it desirable in an erotic context. Prior to her engagement, Pamela rejects all attempts by men who insist upon viewing her through the lens of sexuality. Although Mr. B. inhabits the role of Pamela's opposite and opposing self - a sort of mirror that refracts an image of immorality to the reader-Pamela herself conspicuously refrains from purposefully attracting attention of any kind, sexual or otherwise. In the letters that she writes to her parents - and I am arguing that this production of selfhood is not meant to be a manipulative formulation that Pamela herself creates-, she continuously refers to her attempt to be "a good Girl, and faithful and diligent" person (12). While the hypocrisy of a woman embodying a man's understanding of her self remains evident and something perhaps even beyond hypocrisy—an illegitimate mendacity, perhaps - it is a mute point to Pamela as she fully embodies the state of virginity as a signifier of virtuosity. For instance, during the first of two fainting scenes that occur within the novel, Pamela, while dressing for bed in the room that she occupies with Mrs. Jervis, the housekeeper, argues that her wish to leave the estate is not "Pride of my Heart; but the Pride of my Honesty." She then proceeds to hear an unusual sound coming from the closet, from which Mr. B. "dreadfully" emerges. The scene 
reaches its climax when Mr. B. "found his Hand on my Bosom, and when my Fright let me know it, I was ready to die; and I sighed, and scream'd, and fainted away" (63-64). At the exact moment when she reiterates her commitment to her retain her virtue, Mr. B. emerges to test her it, and it is the physicality of her virtue (or rather, her virginity) that overwhelms her cognitive abilities in order protect her from the assault. As such, it is her righteously held moral intelligence that affects the way that Pamela perceives and protects her self and her body, especially in relation to and as a reaction against Mr. B.'s confinement of her.

What does it mean, then, to conflate virginity with a woman's virtue? It seems absurd to align a person's bodily state with the degree to which their moral intelligence is calculated, and yet it seems as if conflation was not merely evident within eighteenthcentury English culture; it was an ideology that was conceived and visible in texts like Pamela. Harol describes a woman's virginity during the eighteenth century as more than simply pertaining to the biological body, but rather an ideology that exemplifies a value system that was based upon notions of purity:

The particular manifestation of virginity obsession that develops in mideighteenth century England, exemplified by Richardson and Johnson, promotes the notion that virginity's value inheres in its ability to predict not only chastity but virtue more broadly conceived...virginity is superseded, in moral and material importance, by a number of abstract qualities - purity, originality, moral virtue, constancy, and most importantly, marriageability — for which it is a sign and a precondition. Virginity becomes less literal, or at least physical virginity has more metaphorical than literal value. (8-9) 
Virginity, therefore, was the embodied indicator of a woman's state of virtue. The virgin, then, became emblematic of everything that a man could desire in a wife: unpolluted, faithful, unique, and finally willing to serve an obscure state of being simply because she understands it to be moral or right. Mr. B.'s desire to entrap Pamela, who at the beginning of the narrative seems purely nefarious and incomprehensible, becomes at least somewhat coherent when presented within the framework of moral intelligence. It cannot simply be the feminine body that Mr. B. desires as he can and does engage in multiple sexual acts with many different women; but rather, it is Pamela's incessant and unrelenting refusals that render Mr. B.'s desire as ultimately something that is different from what he had experienced with his many other mistresses. Mr. B. discerns Pamela's repeated and steadfast refusals to engage with him and to remain virtuous as something that is malleable and can be transferred from the context of a state of virginity to a state of marriage. It is her repeated performance of virtue that marks Pamela as distinguishable from Mr. B.'s other sexual conquests as he understands her to be ultimately faithful in her system of beliefs and someone who, as it is evidenced, cannot be dissuaded from her convictions.

The use of repetition in texts like Richardson's Pamela are citational performances that render the reader mute or stunned by the constant and unrelenting application. It is the repeated performance that is occupied with meaning rather than the words that are spoken in defense or in action. Readers are, in effect, overcome by the use of repetition and whatever ideology the author is imposing within the text becomes naturalized and obvious. Pamela is forcing Mr. B at every moment to recognize her virtue as something that is itself performative. In other words, it is the repetition or the iteration 
and constant citation of these performances that contain and are replete with meaning. This repeated performance, for instance, can be seen within Pamela in multiple formations, but the most painfully pronounced occurrences are the many and varied ways that Mr. B. attempts to seduce Pamela. His performance is didactic, in a sense, whereby Richardson is coaching both the reader and Pamela herself that Mr. B. possesses a foundational system of morals, in spite of the fact that the deliverance of it is belated. His seemingly misplaced efforts include a solitary embrace, seizure of her letters, kidnapping, attempted rape, a proposal to retain Pamela as a formally recognized and monetarily compensated mistress, and finally a proposal of marriage. His repeated and seemingly unrelenting malevolent behavior becomes something that is almost unbelievable and yet Pamela herself cannot fully escape him despite her repeated and futile attempts to do just that. The continuous exchange between the so-called lovers is at times incomprehensible and so must be read as meaningful in the apparent lack of meaning. It would not make much narrative sense for Pamela to simply acquiesce to Mr. B.'s maneuvers at the first instance, but rather over an extended period of time she comes to understand - though it is a flawed understanding - that Mr. B.'s repeated and unrelenting actions were concerted efforts to woo her. Likewise, Pamela cannot be seen as merely a victim in this instance, as her constant refusals to obey Mr. B.'s libidinous and then morally righteous desires is itself significant.

Repetition can itself be best explained by Jacques Derrida's use of the term "iterative" as it refers to the continued and repeated citation of an (performative) utterance, wherein its very meaning comes into existence through a repeated action or speech act. In other words, to iterate is to make comprehensible and productive meaning 
out of the repeated use of the utterance. Every iterative utterance is then reinterpretation of a specific meaning, wherein that meaning can only ever be uttered with an ephemeral context or signature. The continued repetition of the utterance is the only way for meaning to be inscribed, and that particular meaning can only ever be temporally situated within the context of where it was communicated. So, in the instance of Pamela's and Mr. B.'s repeated interplay, the iterative citation that is employed can only be fully understood within the context of the novel Pamela. The containment, kidnapping, and attempted rapes are extremely discomfiting for both Pamela and the reader, and yet before the novel concludes—well before actually—the actions of Mr. B. have been transformed into something productive, purposeful, and ultimately moral. Clearly a transformation must occur textually in order for the reader to sympathize with Mr. B.; however, this transformation could not have happened without his repeated attempts to seduce Pamela and Pamela's repeated and manifest refusals. The effect of the repeated citation within the text is rendered both didactic for the textual triumvirate-characters, reader, author - and meaningful only within the context of the novel itself. The conduct of both Pamela and Mr. B could never have resulted in the moralized and moralizing conclusion as they exhibit manifestly troubling and contradictory characteristics that can only resemble fictional lives in the plainly obvious fictional world.

The "historicity of force," or as Derrida refers to it, the context, is the very thing that brings the performance into action. As language is wholly meaningless in a vacuum or empty space, the ecological space where speech acts occur becomes the foundation of citational power as the iterative performance becomes ritualized and rooted into a juridical structure that uses both discourse and thereafter physical force to enact power. 
Without falling into a discussion that is purely logo-centric, purely performative, or purely materialist, it is imperative to note that no set of communications or actions that are employed are entirely constitutive on their own, but rather the set of actionslinguistic, performative, and embodied — are combined to inscribe meaning through an incorporation of processes. Meaning can never be wholly meaningless as it is situated in a time and place, and the meanings that are given to signs become then either imbedded or dissociated depending upon the locus of the context. We can see the force of a prior and authoritative set of constitutive conventions occurring within the text of Pamela in the ways that Pamela herself retains and performs her own comprehension or understanding of these seemingly abstract cultural constructions or guidelines. Taken outside of, as Judith Butler phrases it, the historicity of force or put simply, context, Pamela's behavior becomes manifestly indecipherable. And yet, she is at all times operating within the context of her own knowledge system and at what seems to be a very high cost to Pamela herself.

Pamela's moral intelligence is manifested not in a way that renders her actions accessible or understandable to the reader but rather as a way for her to protect the state of virtue that she cherishes above all else. In other words, virtue for Pamela has become something that is innate and embodied rather than discursively or theoretically conceived. In his Essay, Locke writes that:

A man begins to have ideas when he first has sensation...If it shall be demanded then, when a man begins to have any ideas, I think the true answer is - when he first has any sensation. For, since there appear not to be any ideas in the mind before the senses have conveyed any in, I conceive that ideas in the 
understanding are coeval with sensation; which is such an impression or motion made in some part of the body, as produces some perception in the understanding. It is about these impressions made on our senses by outward objects that the mind seems first to employ itself, in such operations as we call perception, remembering, consideration, reasoning, etc. (100, my italics)

Clearly, Locke's theory of human understanding is not compatible with modern theories of cultural construction and ideologies formed through discursive formations. However, Locke's theory as it is can be applied to Pamela's performance within the text, aligns with the notion of a moral intelligence enacting modes of behavior as if they were innately conceived, or as Locke phrases it, understood as "coeval with sensation." Conversely, the understanding of intelligence as it pertains to this chapter is a means of understanding something innately but not entirely coeval with sensation. Thus, Pamela, under this dual consideration, is acting with a great understanding of her own virtuous morality but a morality that has been conceived a priori-knowledge that was not innately understood. Richardson has bestowed Pamela with the gift of a moral intelligence, but it is an intelligence that was conceived purely as a narrative effect rather than something that Pamela was born into. In other words, Pamela's embodied intelligence can only ever be productive within the force of the narrative alone and becomes something akin to hyperbole when taken outside the text—something that is seen in the many and varied responses to the novel.

During the eighteenth century there emerged a theory of sensibility that equated sensory perception as the site wherein knowledge or understanding could be taken in or consumed. The understanding of Pamela's moral intelligence unequivocally corresponds 
to Locke's and presumably Richardson's understanding and incorporation of sensibility as a means for women to counteract immoral forces that were attempting to thwart their status as virtuous beings.

The most evident example of this type of foiling can be seeing in Pamela's attacks of unconsciousness or fainting spells that seem to occur at the precise moment wherein her virtue and virginity are being assaulted. The first episode occurs within the household of Pamela's now deceased mistress, with the seemingly reliable witness Mrs. Jervis close by: "I found his Hand in my Bosom, and when my Fright let me know it, I was ready to die; and I sighed, and scream'd, and fainted away" (63). The second fainting scene occurs likewise when Mr. B. has attempted to rape Pamela; only the trustworthy witness of Mrs. Jervis has been transformed into the thoroughly unreliable Mrs. Jewkes and the site of the attempted rape occurs within Mr. B.'s own household:

--And then, (for this was all detestable Grimace) he put his Hand in my Bosom. With struggling, Fright, Terror, I fainted away quite, and did not come to myself soon; so that they both, from the cold sweat that I was in, thought me dying-And I remember no more than that, when, with great difficulty, they brought me to myself... (204)

Pamela's repeated resistance to Mr. B.'s advances—both sexual and discursive—-seem to define her sensibility as fundamentally embodied. The morality that she employs and thus her ability to functionally or innately understand the implications of what it means to be virtuous is itself defined by her resistance to sexuality. In this instance, Pamela's fainting spells compute not to an intellectual disability—something that will be discussed in the next chapter-but rather as an embodied and reactive mechanism in place to forestall any 
action that she (and her culturally constructed mind) perceives to be immoral. Her mind is not overcome and then crippled by its inability to cohere what is happening, but rather Pamela's moral intelligence can be understood as an automatic cognitive response, an embodied or intuitive reaction to what she interprets as an immoral action.

My understanding of Pamela's behavior and thus her virginity as a marker of moral intelligence can perhaps be better understood within the context of how $\mathrm{Mr}$. B. then perceived and comes to understand Pamela's repeated fainting spells as markers of true morality and moreover, a manifest devotion to her cause of remaining virtuous. If we return to the second fainting spell, wherein Pamela has already been kidnapped and is trapped within the bed by Mrs. Jewkes and Mr. B., the reader is here, at this moment, meant to perceive an alteration in Mr. B.'s nefarious behavior:

[Mrs. Jewkes speaking first] And will you, Sir, said the wicked Wretch, for a Fit or two, give up such an Opportunity as this?-I thought you had known the Sex better.-She is now, you see, quite well again!

This I heard; more she might say, but I fainted away once more, at these Words, and at his clasping his Arms about me again. And when I came a little to myself, I saw him sit there, and the Maid Nan, holding a Smelling-bottle to my Nose, and no Mrs. Jewkes.

He said, taking my Hand, Now will I vow to you, my dear Pamela, that I will leave you the Moment I see you better, and pacify'd. Here's Nan knows, and will tell you my Concern for you. I vow to God, I have not offer'd any Indecency to you. (204) 
Mr. B. has been exposed to Pamela's embodied disgust at his sexual advances at least three times, and up to this point in the narrative he has not desisted in his attempts to seduce Pamela. Why, then, does Mr. B. verbally introduce his stated concern for Pamela at this specific juncture? As Mrs. Jewkes so pointedly argues, Pamela is prostrate upon the bed, seemingly unconscious and ready to be taken in any number of ways, most obviously to be raped by Mr. B. And yet, it is this scene wherein Richardson reintroduces him as a figure that can employ empathy if he so chooses. Logic would argue that Pamela's repeated and unrelenting performance has irrevocably transformed $\mathrm{Mr}$. B. into a person who has undergone his own sort of moral awakening. Seemingly, it is here that Mr. B. finally becomes aware that Pamela is not feigning her fits of unconsciousness or teasing him with her continual refusals. Her sensibility, as it were, has been transformed from something that must be overcome to something that must be protected.

Women who fainted in literature were often seen to employ this tactic as a way to avoid any undesired sexual encounters. G.J. Benfield-Barker argues that women in socalled sentimental fiction who displayed "symptoms of a nervous disorder" when encountered with a sexual offer were often perceived in the moment of the fit as vulnerable and in need of guidance and protection, but after such occurrences the women would often be perceived as somewhat tainted by the sexual encounter:

... according to the evidence of sentimental fiction, the ambiguous values of a fine "sensibility" took on a particular meaning in the relations between women and men. The aggrandizement of a certain kind of consciousness on the one hand was associated with the powers of intellect, imagination, the pursuit of pleasure, the exercise of moral superiority, and wished-for resistance to men. On the other, it 
betokened physical and mental inferiority, sickness, and inevitable victimization, circumstances throwing severe doubt on the effectiveness of the female will. (3536)

Barker-Benfield raises an important point regarding feminine will and women's lack of power over decisions that concern themselves and their bodies. While I too see Pamela as outside the parameters of sexual desire, her own that is, her fainting spells must translate to more than a seeming lack of desire. As Mr. B. initially locates Pamela's constant refusals as mere invitations to repeat his own advances, Pamela clearly employs an embodied intelligence that signifies a considerable understanding of how to at once navigate a seemingly terrifying world of men and protect what she considers to be her most valued possession: her virtue.

While Mr. B., conversely, does not possess Pamela's morality, he does possess a sexual intelligence which enables him to become a predator. Pamela cannot conceive intelligently of sexual desire and thus is rendered initially dumb, and more insidiously, accessible to Mr. B.'s desires. It is only through his conversion via Pamela's example that allows for Mr. B. to transfer his intelligence from that of predator to one of protector. Pamela's moral intelligence then becomes the complete negation of desire, where desire is suppressed not in the sense that Pamela is fundamentally unable to express her desire, but rather that desire is unintelligible to her because it is not within her understanding of morality. Seemingly, sexuality and sexual desire are outside the parameters of a moral system wherein sex is used in a productive capacity rather than to satiate a purely subjective and personal desire. 
The cognitive literary theorist Lisa Zunshine argues, "we perceive people's observable behavior as both a highly informative and at the same time quite unreliable source of information about their minds" (119). Taking this understanding of one's perception as a source of information, we can locate Mr. B. as one who perhaps initially perceived Pamela as an unreliable narrator of her own desires. Mr. B. was immersed within a culture that permitted men's desire to both overcome and reign over a woman's desire, sexual or otherwise. So, only through Pamela's repeated and unrelenting citations of her own morality could Mr. B. become aware of what she was desperately attempting to convey. Zunshine argues that cognitively, we are wired to perceive the embodied discourse of those around us:

Our neural circuits are powerfully attuned to the presence, behavior, and emotional display of other members of our species. This attunement begins early (since some form of it is already present in newborn infants) and takes numerous nuanced forms as we grow into our environment. We are intensely aware of the body language and facial expressions of other people, even if the full extent and significance of such awareness escape us. (118)

Zunshine importantly points to the language of the body and its fundamental importance for human inter-relations. Pamela, although vulnerable in the patriarchal socio-economic structure, is able to express and influence her moral sensibility toward Mr. B. through continuous and repeated applications. As such, her cognitive processes shift from what may appear to be automatic processes to an active intelligence that is grounded in a very rigid sense of morality. 


\section{CHAPTER III}

\section{VIRGINITY AS INTELLECTUAL DISABILITY}

In the previous chapter, I outlined my definition of moral intelligence as a person's ability to at once embody an expressly felt knowledge in their person and perform their righteously held understanding in a manner that affects not only the use of their body as a reaction against their lived circumstances but also how others perceive and make use of the body as well. Richardson fashioned Pamela's intellectual center upon her embodied sense of virtue; that is, her virginity. This fixed and particular form of embodied morality resulted from Richardson's interest in his character's moral and religious self-examinations, but it is important to note that although Pamela's virtue was rewarded at the conclusion of the novel, novelistic depictions of virtuosity and more to the point, moralistic punditry, was considered farcical and lacking verisimilitude in a world that was experiencing radical social and economic shifts.

Richardson has bestowed Pamela with the gift of a moral intelligence, but it is an intelligence that was conceived purely as a narrative effect rather than something that Pamela was born into. In other words, Pamela's embodied intelligence shifts into the realm of hyperbole when taken outside of the text; the containment of the narrative alone allows Richardson's hyperbolic prose to be productive - something that is evident in the many and varied responses to Pamela. 
This chapter offers a counterpoint to the first. Here, virginity, as intellectual disability, relates to intelligence as a site of imprint, similar to the notion of the tabula rasa, a Latin phrase meaning scraped tablet or blank slate (OED). Locke clarifies this idea in his Essay as the "mind to be...white paper, void of all characters, without any ideas; how comes it to be furnished? ...To this I answer...from experience: in that, all our knowledge is founded; and from that it ultimately derives itself" (33). Locke is setting the terms for his discourse on free will and the self-derived identity, which for a seventeenth- century European male is amenable. But for a woman during this period, this kind of intelligence is neither innate nor self-authored. Rather feminine intelligence is defined by masculine discourse as disparate and inherently lacking. A woman's intellectual capacity becomes a cultural construction that is used to define a specific and gendered intellectual disability.

In order to move forward with this argument, it should be noted that I am defining intellectual disability as an ideologically based imperative that restricted women's movements and enabled a system of patrimony, wherein women's bodies were commodities within a sexual marketplace, to flourish. This discussion is not to be confused with current academic discussions regarding physical and intellectual disabilities as forms of discrimination, or in discussions regarding able versus disabled bodies. Rather, I am positing that a woman's virginity can be used as a locus for imprinting notions of vulnerability and naïveté, which are then used to broadly construct "women" into a diminished class who are conceived of as innately disabled or in other words, in need of guidance and protection. I am interested in examining both the ways women in literature have been acculturated by systematic patriarchal endeavors and how 
the responses to Pamela ultimately reinforced ideologies that shaped virginity as not only a physical state but also an intellectual disability. Within this chapter, I aim to look at the different ways intelligence was defined for men like Richardson and his literary progeny and how the response to the hyperbolic and didactic prose within Pamela failed to engender or provide any intellectually enabled and realistic versions of Pamela.

Samuel Richardson was first and foremost a printer during the age of Enlightenment. During this period, booksellers and printers were continuously and "consciously adding the body of knowledge and provoking debate. Printers stood at the center of a continuous exchange of ideas" (DLB, 39). Richardson was born in 1689, just one year after the Glorious Revolution and 40 years after the execution of Charles I. His generation inherited an English identity that was rooted in public struggles over political and religious power, and perhaps it was this sense of disaffiliation and anachronistic shifts within the power structure that fed into the libertinism and immorality that populated Restoration era literature and culture. Richardson's texts, although written much later during the 1740 s, was certainly influenced by an early sense of impropriety within the structures of power or at the very least doctrinal instability. His disaffection with social immorality and abuses by men in positions of power are clearly represented in his writing, beginning with The Apprentice's Vade Mecum and echoing all the way to Charles Grandison. But where did his sense of moral understanding come from and moreover, why did he feel compelled to articulate his beliefs in what is now considered an early form of the modern novel?

The compunction to disseminate information that was of a sound moral quality and provided the reader with a purpose perhaps can be linked to Richardson's familial 
religious background. The Richardson family was Protestant with echoes of Puritanism, although Richardson's own beliefs are somewhat more difficult to articulate, as he himself never was expressly explicit on the matter. John Dussinger writes that "a basic tenet in Richardson's writings is against the idea that 'Religion was design'd to contradict Nature'; he emphasizes instead that it is the only way to fulfil our imperfect nature" (New \& Reedy, 33). Likewise, in his essay “Samuel Richardson's Clarissa and the Problem of Heaven," E. Derek Taylor notes that Richardson "claimed to be a Puritan, a via media Anglican, a Boehmian mystic, and a closet secularist ... It is just like Richardson ... to take his inconsistencies into the great beyond, even in his most sustained and carful thinking on the topic ..." (New \& Reedy, 77). While Richardson may not have adhered to a specific Protestant doctrine, he was clearly concerned with the moral responsibilities of those in power and the degrees to which intellectualism — which could only be accessed through the class sanctioned education system—necessitated the moral obligation of those who were privileged enough to be a part of what is now considered the age of Enlightenment.

The period in which Richardson spent as an apprentice for the printer John Wilde may perhaps hold one answer as to why Richardson the novelist was interested in immoral and unscrupulous behaviors by those within the apex of power structures. Margaret Ann Doody writes that he chose the profession of Printer because he thought it would satisfy his "Thirst after Reading," and was not in any way related to joinery, his father's choice of profession:

The seventeen-year old apprentice found the work hard, serving 'a Master who grudged every Hour to me, that tended not to his profit, even of those times of 
Leisure and Diversion, which the Refractoriness of my Fellow-Servants obliged him to allow them, and were usually allowed by other Masters to their Apprentices.' This account exhibits a lingering bitterness toward John Wilde, who did not reward the virtue of the young apprentice who was too proud to break any rules, even though he had other pressing interests: 'I stole from the Hours of Rest and Relaxation, my Reading Times for Improvement of my Mind; and being engaged in a Correspondence with a Gentlemen greatly my Superior in Degree...these were all the Opportunities I had...to carry it on.' Yet he adds, he took care 'that even my Candle was of my own purchasing,' and was careful 'not to disable my self by Watching...to perform my Duty...in the Day-time.' The scrupulousness reflects the pride of a very independent person who can never be truly happy under the command of another. (381)

Doody's description of the young Richardson can be easily measured against the character of Pamela: they both seek guidance from others who in their estimations are 'superior in degree.' Despite the regulations or restrictions placed upon themselves during their long working hours, they both recognize intellectual endeavors-reading for Richardson and writing in the case of Pamela — as not simply an interest that may imperil the precarious status they hold with their employers, but rather as the very thing that maintains their ability to survive in such hostile environments. Doody's passage is important as it allows us to restructure our notions of Richardson from an author mocked for his moralizing and hyperbolic writings to a person, although later a very powerful printer within the Stationers' Company, who was very much affected by the ill treatment that he experienced during his apprenticeship. 
Richardson's rise from a lowly but resolute apprentice in 1706 to Master of the Stationers' Company in 1754 "implies a determination to succeed, a steady persistence over the years, and a reputation among his fellow members for having at heart the best interests of the London book trade" (Maslan, 7). This stated reputation is curious when considered against the very well documented Pamela controversy and the degree to which Richardson himself was criticized for the writing and printing of Pamela. From the first printing in 1740 until his death in 1761, Richardson issued ten editions of Pamela, each in its way attempting to appease his critics of "high degree" who took exception to both the manner of Pamela's improvement in station and the vulgarity of her "stile" or discourse. Put simply, he could in no way afford the weight of criticism from members of the aristocracy, as his very livelihood rested upon contracts that he had cultivated from such friends. In 1733, Richardson was appointed the Official House of Commons printer, although he had been unofficially printing Parliamentary documents for over twelve years prior to his appointment: "all Parliamentary (and legal work) offered the master a margin approximately double that for booksellers' work, even if payment could be slow in coming" (Maslen, 15). Richardson's hard-won status as an influential printer within the Stationers' Company is no doubt linked to his contacts within the higher ranks of society; so when one considers his repeated attempts to reassert control over Pamela's text, Richardson's revisions are manifestly linked to the anxiety surrounding the material conditions of his position with the City and his reputation as a moral standard. Thomas Keymer and Peter Sabor write that critics have sometimes overstated Pamela's credentials as a working class heroine, not only because of the anachronistic connotations of 'class' in a society 
still organized by traditional stratifications of rank, but also because Richardson was careful to modify her lowness with traces of ancestral respectability: as George Cheyne wrote, with only slight exaggeration, 'Your Heroine you have made a Gentlewoman originally and distinguished only [on her marriage] by some Ounces of shining Metal' ... Nonetheless, there can be no question that for... writers of the controversy Pamela did indeed present an affront (albeit sometimes a welcome affront) to hierarchical assumptions... (6).

Both Pamela and Richardson exist within an illusive and unstable stratum of social hierarchies. They can neither fully and comfortably rest in the stations that held them at birth nor can they lie easily within the stations that they have risen to. The point of interest, then, must arise from Richardson's (and by proxy, Pamela's) bifurcated allegiances - to both his internal misgivings surrounding the advantageous immorality of people who are in positions of power and his allegiance to benefactors who were affiliated with the very class Richardson sought to correct.

Considering these dual allegiances and Pamela's placement within the unstable social hierarchy, the reader and critic should hardly be surprised at Mr. B.'s perception of and behavior toward Pamela. At the age of fifteen she is neither fully woman nor simply a child, and her status as an enslaved servant under the domain of a master is fully recognized by Mr. B. When Pamela first refuses his advances in the famous garden house scene, Mr. B.'s responds by alighting upon this recognition: "I was preceding: and he said a little hastily—Because you're a little Fool, and know not what's good for yourself. I tell you, I will make a Gentlewoman of you, if you be obliging, and don't stand in your own Light; and so saying, he put his Arm about me, and kiss'd me!" (23). The text is 
saturated with Mr. B.'s inflammatory derisions of Pamela. He rebukes her with names such as "little" or "foolish Hussy," "Slut," "artful deceiver," "Creature" and so forth. The names that are innumerably used to describe Pamela are almost always attached to a diminutive adjective like "little" or "foolish" to imply Mr. B.'s construction of Pamela as both naïve and experienced, at once child and adult. From a critical perspective, perhaps the novel's foundation is Mr. B's attempt to fashion Pamela into a woman of high culture through a rigorous program, a masochistic educative service by way of Pygmalion.

The varied positions and statuses that are ascribed to Pamela (daughter, object of desire, and wife) are presented as malleable and never fully realistic within eighteenth century class hierarchies. In the section of his "The History of Intelligence" entitled "Intelligence and Disability: Status and Power," C. F. Goodey writes of intelligence as a form of social classification and a form of self-representation based upon one's honor and grace:

Important to legitimation [of a person] is precedence. Each mode is competitive within itself: struggles take place wherever precedence is intrinsic but the outcome in doubt. Each group has its own technical gradations of excellence...that are also presented as moral gradations. In addition, if communities of honour, grace and intelligence are circumscribed by the vulgar, the ungodly, and the disabled respectively, there are also groups whose bid is ambiguous. Alongside honourable gentlemen are gentle women, whose honour is something quite different from men's; alongside the godly are those whose state of grace mere mortals cannot know; alongside the intelligent are those whose status is ambiguous because postponed, such as children ... (67-68) 
The point that Richardson is attempting to convey within this bewildered plot is that Pamela employs an innate sense of honor and grace, one that is neither pre-determined by her social status nor by the locus of her virtue. Rather, Richardson believes Pamela to be outside of the normalized and restrictive social constructions that inhibit others within the hierarchy. Pamela is not a mere servant girl, nor later is she merely a gentlewoman: Pamela's condition is what Goodey describes as something "mere mortals cannot know,"; she is the exception to the rule and this exceptionalism is why everyone from the fictional Mr. B. to critics of the novel itself so freely hurl insults at her. Goodey continues the discussion of grace and honor by adding:

Friction also arises from the contradiction within each bidding mode between the porousness of borders... and the fact that membership is super-determined by a necessity that is beyond time or place. Thus there is tension between status ascribed and status achieved. Is my innate honour subject to fate, or can I act to rescue it? Am I saved by God's predestined grace, or can I work at my salvation? Is my intelligence determined by my DNA, or is it improvable by nurture? These debates are the contentious political face of the modes ... (67-68)

The reaction to Pamela is unmistakably connected to how readers and the public in general prescribed and adhered to social hierarchical structures. To use Goodey's term, the "porousness" of Pamela's status - the incongruous state of her virginity, her shifting position with the household—is the very thing that renders Pamela herself as unbelievable. The tension between the status ascribed to her (being the daughter of Goodman Andrews) and the status that she achieves through both the desire that Mr. B. 
holds for her and their eventual marriage was never reconciled to the public as a realistic portrayal of moral boundaries, desire, and marriage.

Pamela's status as neither fully servant nor fully wife is always present within the text, and to state that women have been perceived within Western culture as child-like half-adults who reside within a permanent stasis of immaturity is certainly not revolutionary. However, understanding the process of legitimization that must occur for a woman to transform from a child to virgin to wife and then finally to matron is important within the context of Pamela as her intelligence and material form are always situated within a malleable state. At no point in this process is the female ever recognized (at least not by the patria) as agential. The site at which a child becomes sexualized is often blurred by claims of ownership and then of derision. Mr. B.'s recognition of Pamela's body as a site of sexual pleasure is exacerbated by the vitriolic diminutions that he prescribes to Pamela. It is precisely because her body is in a state of transition that Mr. B is allowed, or to go further, proscribed to act upon it. The material condition of Pamela's virginity has been constructed in such a way that it allows for an erasure of immorality for Mr. B. In other words, Mr. B is sanctioned by both his social status and his gender to explore any sexual perversions upon Pamela's body so long as she is rendered mute prior to his as-of-yet legitimate marriage. During her period of confinement in Leicestershire, Pamela makes a similar declaration regarding both her status as a servant and as a virgin: Here, said I, were my poor honest Parents; they took care to instil good Principles into my Mind, till I was almost twelve Years of Age and taught me to prefer Goodness and Poverty to the highest Condition of Life; and they confirm'd their Lessons by their own Practice; for they were, of late Years, remarkably poor, and 
always as remarkably honest, even to a Proverb; for as honest as Goodman Andrews, was a Bye-word ... My Good Pamela, be virtuous, and keep the Men at a Distance: Well, so I was, I hope, and so I did; and yet, tho' I say it, they all loved me, and respected me; and would do any thing for me, as if I was a Gentlewoman ... and then comes my Master. And what says he?-Why, in Effect, it is, Be not virtuous, Pamela ... (200)

Pamela's ability to recognize herself as a pawn, a blank slate with which Mr. B. can do with as he likes is demonstrative of her anomalous characterization: the adversity that underlies Pamela's situation is the very thing that renders her atypical.

In a scene that shortly follows the above episode Mr. B. alters his strategy towards Pamela from overt and imperious sexual desire to one that demonstrates adoration and a wish to legitimately confirm his desire: "Charming creature, lovely Pamela, said he, (with an Ardor, that was never before so agreeable to me) this generous Manner is of a Piece with all the rest of your Conduct. But tell me more explicitly, what you would advise me in the Case" (214). Prior to this scene, Pamela has been governed by the moral instructions of her father, but here is one of the first occurrences wherein she overtly shifts her deference to Mr. B. Both his insistence that she tell him what he ought to do and her declaration that his "Ardor, that was never so agreeable" marks an alteration in his attendance toward Pamela. In effect, Mr. B. is endeavoring to articulate his will upon her body, rendering her as both a blank slate and a pawn for his desires.

As was discussed in chapter 1, many believed that one's morality was a marker of Iplace within society, so Richardson created Pamela to demonstrate that even the most powerless entities could overcome their nascent disability and rise above to their 'proper 
stations.' Where the text diverges from the normalized and normalizing narrative is Pamela herself: she rejects the conscription of her body as a sexual commodity for Mr. B. and instead remains determined to overcome the assigned naiveté that is intertwined with the state of virginity. Until the point in which Mr. B. is revealed to have altered his predatory manner, the narrative frustrates itself with Pamela's inability to rectify the nature of her condition. As a child she was educated upon the principle that morality and virtue were intrinsically connected with one's embodied and intellectual performance, and yet she, virtuous in both mind and body, has been abused and concealed for acting in what she considered the most honorable and moral fashion:

So here have I lived above sixteen Years in Virtue and Reputation, and, all at once, when I come to know what is Good and what is Evil, I must renounce all the Good, all the whole sixteen Years Innocence, which, next to God's Grace, I owed chiefly to my Parents and my Lady's good Lessons and Examples, and chuse the Evil; and so, in a Moment's Time, becomes the vilest of Creatures! And all this, for what I pray? Why, truly, for a Pair of Diamond Ear-rings, a Necklace, and a Diamond Ring for my Finger; which would not become me: For a few paltry fine Cloaths; which when I wore, it would make but my former Poverty more ridiculous to every body that saw me, especially when they knew the base Terms I wore them upon (200).

This passage importantly alights upon Pamela's very real intellectual ability and acumen. Despite all of her efforts to repeal Mr. B.'s advances, she still remains his captive. And despite her intact virginity, Pamela is clearly able perceive the situation at hand. She is able to overcome the imprint of naiveté that she once bore and recognize her situation as 
not only dire but also with an almost retired resignation, something that only a person with a great deal of intelligence can understand. Pamela, like Richardson, becomes the beset yet determined apprentice who must overcome an appalling circumstance in order to rise in status and degree.

It is this conferral, however, that brought about the most criticism for Richardson. Critics reacted boldly to Pamela for a multitude of reasons, but Richardson took it upon himself to rectify the low opinions that his benefactors and those within the gentry held of Pamela. In what is considered the first review of the novel, the publication The History of the Works of the Learned was careful to praise Richardson's effort except in one portion of the text: "The Language is not altogether unexceptionable, but in several Places sinks below the Idea we are constrained to form of the Heroine who is supposed to write it" (Keymer \& Sabor, xi). Pamela's "high stile" was objected to precisely because Richardson located virtue within an already presumed immoral body. Keymer and Sabor argue that although this criticism is moderate in its tone, it "inaugurate[d] a strain of objection ... that would become a major theme of Pamela's early reception. Though obviously inappropriate to a work attempting to simulate a servant's letters, complaints like this followed inevitably from the established assumption that good literature involved high style" (x). The controversy that followed brought about discussions surrounding the moral implications of master-servant sexual relationships, false portrayals of cross-class romances, and most pertinent to our discussion, the nature of virtue versus vice and more to the point, the shameless debauchery that many considered Pamela's rise to be, from serving girl to Lady of the estate. Despite Richardson's initial effort to model Pamela as virtue incarnate, the public could not regard Pamela as a 
woman who was innately virtuous or good. Rather, the majority of the reading public perceived Pamela as the manipulative figure, the very opposite of naïve. Many readers doubted the authenticity of Pamela's virtue and located the nexus of her vice to be the very thing that she fought so hard to protect: her virginity, or rather, the lack of it. Popular opinion was slanted toward Pamela the vixen rather than Pamela the virtuous. This disbelief should not be taken lightly. Although the text itself does tend at times toward the hyperbolic, Pamela in no way displays any signs of malice or manipulation toward Mr. B; rather, it is he who on several occasions attempts to rape Pamela, and it is he who misdirects her carriage and keeps her captive in his country estate:

For now, he seems to abound with Kindness, and talks of Love, with Reserve, and makes nothing of allowing himself in the Liberty of kissing me, which he calls innocent; but which I do not like, and especially in the manner he does it; but for a Master to do it all to a Servant, has Meaning too much in it, not to alarm an honest Body. (208)

Why then, is the public opinion so low of Pamela? The answer seems obvious but the above passage contains such a powerful miasma of woe and resignation that surely the public opinion would engender sympathetic feelings towards Pamela's situation, if not to Pamela herself. Why do they not trust her given word that she is indeed virtuous and virginal? More to the point, why do readers insist upon conflating a woman's virtue with the physical state of her body and choose to assume that she is not simply lying about the state of her virtuosity but rather, she is the very opposite of virtuous? The answer must lie within the very strict system of class hierarchies. No care was to be given to a servant child cum woman who allowed herself to be looked upon and perceived as beautiful. 
Corrine Harol argues that "one of Pamela's most clever strategies, in terms of its response to gendered representations of virginity, is that it transfers the interest in virginity from Mr. B. to Pamela. By making Pamela the defender of her own virginity, more concerned with it and valuing it more highly than Mr. B. does, Pamela displaces anxiety over virginity from the male to the female" (136). The strategy is indeed clever, but in this displacement Richardson has transferred the weight of a cultural construction - a construction that no doubt was conceived as a way to control the feminine body—from a masculine anxiety to a feminine responsibility. This burden is much too heavy for a figure like Pamela because she is operating within a theatre that disallows feminine free will, and as such, the reading public mocked her in her attempts to prove her virtue. Harol continues in her argument by pointing to the mystery of the early modern female body and men's inability to prove a women's virginity and thus also her virtue:

The emergent ideal of female virtue depends on thoughts, feelings, and intentions, not merely on actions or physical signs. Pamela's virginity is a necessary condition of her virtue, but it is not sufficient testimony on its own. Pamela's journal renders Pamela's interiority—like the body on an ideal dissecting examination, with a plausible pretense to objectivity. Mr. B.'s obsessive interest in reading her letters and journal is evidence that he believes her words have the status of, or at least provide some access to, truth. In giving priority to virtue over virginity, the novel makes Pamela's inscrutable and private body less relevant than her thoughts, and it promises the reader unfettered access to those thoughts through the journal form. (138) 
Pamela's words, rather than her body, are laid bare to the reading public, but access to her most private inner dialogue surely must be as painful as the sexual assault that she also endured. Richardson's shift from epistolary form to journal form occurs at the very moment when Pamela is taken into captivity. Her public words become private thoughts, and much like her insistent and incessant pleas for her parents to believe that she is still their "honest daughter," her journal is written to an inner audience; she now pleas with herself to render her experience intelligible. Pamela's vulnerability and naïveté become manifest in her inability (or dis-ability) to improve her situation. Her public pleas become private misgivings about her ability to escape from Mr. B.

But just as Harol implicitly articulated, Mr. B.'s obsessive attention to Pamela's letters is a direct manifestation of his sexual desire for her. His stealthy attempts to uncover Pamela through her letters must be read as a symbolic representation of his obsession with her body:

I wish, he said, I could avoid thinking so well of you, as I do. But where are the Papers? - I dare say, you had them about you yesterday; for you say in those I have, that you will bury your Writings in the Garden, for fear you should be search'd, if you did not escape. This, added he, gave me a glorious Pretence to search you; and I have been vexing myself all Night, that I did not strip you, Garment by Garment, till I had found them. O fie Sir, said I; let me not be scar'd, with hearing you had such a Thought in earnest. (238)

If Mr. B.'s is seeing truth in in Pamela's words, as Harol describes it, he is also seeking to uncover truth in her body: the words in her letters act as a pathway or direct entrance to her body: if Mr. B. can discover the "true" meaning of Pamela's words, then he also has 
access to her stripped and denuded body. As feminine virginity has been constructed as a site of disability, then Mr. B. has been granted permission to expose Pamela though both material and metaphorical means. That is to say, by reading and handling Pamela's letters, Mr. B. is performing a sexualized and ritualistic fantasy which authorizes him to physical engage or molest her: he is seeking an encoded permission from Pamela to do what she has, in verbal terms, forbidden him to do. Richardson confuses Pamela's journal with her body in the second part of the novel. He encodes her physical body, or rather her virginity, as the site of disability, and transfers her intelligence to her written and concealed words. 


\section{CHAPTER IV \\ THE LOSS OF VIRGINITY AS INTELLECTUAL ENABLING}

The crisis concerning the female body and its ability to engender immoral feelings in both the passive and active sense disabled figures like Pamela who were constructed so precisely and in such a socially idealized manner by displacing the origin of erotic reaction upon the woman rather than upon the man. As was discussed in the previous chapter, the besieged Pamela becomes a misnomer for the virtuous maiden as both the novel and the character were mocked for her abundance of virtue and seeming lack of artifice. Despite the troubling reversal of feelings Pamela displays toward Mr. B., the Pamela from the early and middling parts of the novel varies greatly from the Pamela-inlove: the novel opens with her outright disgust of Mr. B. and his callow behavior but ends with Pamela displaying symptoms of what is popularly known as Stockholm syndrome, when she submits to Mr. B.'s proposal of marriage.

Richardson carefully constructed Pamela's awakening to Mr. B.'s advances so that their romance appeared to grow in earnest rather than through any deception by Pamela, much less the overt deception that Mr. B. actually undertakes. This careful construction forbears any real responsibility upon Mr. B., so much so that the reader is roughly led to believe that he had never intended to do any real harm to Pamela. 
But it is important to note that from the opening of the novel Mr. B. is drawn as a figure who immediately gains power over Pamela not simply because he is her employer, but because he is explicitly aware of his status as a landowner and his ability to circumvent the stated moral conventions over his desire for Pamela's body. From the welldocumented public reactions to the novel, we know that many readers felt Pamela herself was to blame for her kidnapping, attempted rapes and eventual cross-class marriagethat indeed, she exploited Mr. B.'s goodwill by inciting an uncontrollable desire within him. But what is the reader to do with the transition of Pamela's hatred of Mr. B. to her desire toward him? If, as was earlier argued, Pamela is a novel that is acutely concerned with the abuses of power that occur within structures like class hierarchies and patriarchy that forbid criticism, it is important to note that Richardson constructs Pamela as a sort of bildungsroman and as a novel that attempts to refigure morality as an internal and embodied rather than external or class-based characteristic. Pamela's virtue is ostensibly derived from her resistance to any penetrative act on her body, but of course this resistance is simply a manifestation of a moral code that was constructed as a means for the patria to control women's bodies through commerce. Mr. B. has gained control of Pamela's person through an economic transaction and despite his abusive behavior, Pamela's resistance to Mr. B. and any potential penetrative act is always framed by hints of a desire, whether it is for the improvement of Mr. B.'s character, a desire to escape captivity, or a desire that is sexual in nature. Pamela's desire is shaped threefold by her experiences as a young woman living under the graces of a kind mistress, a captivity that is highly sexualized and by the unrelenting naming of her body as a source of sexual gratification. It would seem as if Pamela's journey, or her bildungsroman, is not really a 
novel about a woman whose virtue invalidates her captor's immoral intentions, but rather it is concerned with the repression of feminine sexuality and the process of humiliation that she must undergo in order for her desire to be realized. Pamela is ultimately a novel about shame and desire rather than virtue and resistance.

This chapter follows logically from the previous one as I seek to examine how the loss of virginity (an action that Pamela and Richardson fought so hard to restrain in the first and middle parts of the novel) and agential feminine sexuality authorizes figures like Pamela and Eliza Haywood's Fantomina and Syrena Tricksy to become intellectually enabled. Their loss of virginity is a narrative moment that is often overlooked as agential and a moment that is related to cognitive empowerment or intellectual authority for women. I will look closely at how these figures are depicted cognitively following that "loss" as I hope to locate both Richardson and Haywood as authors who are able to move beyond the anxiety that surrounds feminine virtue once their respective characters have lost the veil of virginity. Pamela, Syrena, and Fantomina are not naïve and unsophisticated beings but rather women who are cognizant and mindful of their discursive and physical behaviors and seek to represent themselves as such.

Pamela and her inverse persona Syrena Tricksy in Anti-Pamela are superficially archetypal in their Madonna/whore dichotomy, so much so that it is difficult to locate either of them as characters who are radical in their feminine nature or as women who offer the reader a fundamentally nuanced portrait of their gender. In each of their narratives they are so often described as either the definition of a virtuous maiden or excessively rapacious in their sexual and monetary greed that any nuance that is provided is lost in a sea of hyperbole. In Pamela's narrative she is written as singularly virtuous, 
and this singularity makes it difficult for the critic or reader to identify her as employing a self-authored free will. Likewise, while Syrena Tricksy can be described possessing free will, she was written by Haywood as an immoral caricature of Pamela and her indefatigable quest to secure a wealthy husband is so unwavering that she can neither be read by the audience as inhabiting nuance nor as fundamentally radical in her (immoral) nature. Fantomina, however, is neither so wholly virtuous that she is disallowed an intuitive moral intelligence nor is she so immoral that she is heedless of any consequence that may appear in her way. Rather, she is drawn by Haywood as outside of the normalized and normalizing lines of angel/demon or Madonna/whore and is figured as both virtuous in her devotion and unprincipled in her action. Fantomina is a woman for whom constancy rather than morality is the guiding directive of her virtue. In Pamela, Anti-Pamela, and Fantomina, the protagonists are guided by a principle that defines their persona, and once they are eschewed of their virginity, each, in her own specific way, is represented as cognitively distinct from her prior self.

Anti-Pamela was written by Eliza Haywood as a rebuke against Richardson's portrayal of an uncompromisingly virtuous young woman and was published in 1741, mere months after Pamela's original publication date. In her introduction to Anti-Pamela, Catherine Ingrassia argues that "Haywood seems to be offering a cautionary tale to the women - and men — who misread not only Pamela but her earlier fiction as well. AntiPamela suggests from the beginning that all emotions can be feigned, and uncalculated behavior may not exist; Haywood cautions her readers from relying too heavily on their immediate interpretation, urging, instead, that they never take anything at face value" (36). This recommendation can as well be directed at the many responses that Pamela 
elicited, and Ingrassia is correct in her evaluation of Anti-Pamela as a text that forces its readers to reconsider their assumptions, insular social constructions, and moral considerations as if not false, then certainly willful and pre-determined. Haywood has constructed Anti-Pamela as a sort of "anti-conduct book...or [unlike Richardson] a conduct book for women interested in transgressing convention" (Ingrassia, 35). While I do not read Pamela's protagonist as deliberately calculating her eventual marriage to Mr. B., I can surely understand Haywood's and others' reactions against Pamela, as Richardson's tone was often didactic and Pamela was marketed as an epistolary meditation or narrative sermon on the "true" meaning of virtue.

While written within the framework of parody, Anti-Pamela presents an inverse realism to Pamela's secluded and insular domestic world, one where the crisis of the feminine body is presented as not simply the fault of the woman. Rather, any sexual anxiety that surrounds Syrena's body is immediately coopted by her for her own financial gain. Ingrassia continues in her argument by stating that "Anti-Pamela is a complex novel that offers an alternative didacticism that teaches cunning, duplicity and, ultimately, selfsufficiency within the treacherous financial and sexual economies women confront" (37). Syrena is certainly the anti-Pamela, but she is no less constructed in her machinations than Pamela is in regards to her uncompromising virtue: whereas one woman strives to maintain her status as a virgin, the other relishes in the freedom its loss provides for her.

The narrative of Anti-Pamela is so densely packed with Syrena's exploits that the loss of her virginity can easily be overlooked by the reader as an important narrative moment. Within the first lines of the novel, Haywood is careful to present Syrena as infinitely beautiful but even more infinitely duplicitous: 
Syrena was a Girl, who even in her Cradle gave the promise of being one of the compleatest Beauties of the Age: As her Years encreas'd, and her features grew more settled, her Loveliness encreased in Proportion: but what was most to be admired in her was, that the Innocence which is inseparable from Infancy, and which is so charming, even in the plainest Children, never forsook her Countenance; but continued to dwell in every little Turn and Gesture long after she came to Maturity, and had been guilty of Things, which one would think should have given her the boldest and most audacious Air." (53)

Syrena's beauty was emergent with her feigned innocence: the two could never be separated. Likewise, Syrena was, by her mother cum collaborator, "train'd up to deceive and betray all those whom her Beauty should Allure..." (54). Haywood's response to Richardson's novel is a catalog of Syrena's many attempts to capture a wealthy husband and the catastrophic failures that result from each encounter. Syrena is nothing if not persistent in her failed attempts, and while these attempts are clearly hyperbolic in their orchestration and delivery, the crucial moment within the narrative is not Syrena's marriage to a wealthy man; rather, it is the sexual encounter that she has with Vardine and the resultant loss of her virginity. Haywood portrays Syrena as possessing an innate immorality or impartiality: she is vice to Pamela's virtue. However, Haywood clearly renders Syrena as fundamentally altered by her first sexual encounter and the loss that she experiences engenders an intellectual empowerment that inculcates agential, if not seemingly masculine, characteristics:

As Syrena had a Share of Understanding uncommon for her Years, she could not recollect what had pass'd between her and Vardine, without a great deal of 
Uneasiness; but her Vivacity and Strength of Spirits soon threw it off; she consider'd that as it was past recall, to hurt her Eyes and Complexion, by crying and fretting, would increase not diminish her Misfortune; and therefore resolved to be entirely secret in the Matter, and get as much as she could from him in recompense for what he had robb'd her of. (77)

In direct contrast to the fainting spells that overwhelmed Pamela in her encounters with Mr. B., Syrena's consideration and then resolve to receive "recompense" from Vardine is almost disconcerting to a reader who encounters Pamela and then Anti-Pamela. But what do we (readers) know or presume to understand about the minds of the characters at play in novels as interconnected and yet as disparate as Pamela and Anti-Pamela? Within the narratives of these two novels are characters who are obverse representations of the same persona, always working in opposition to one another. Readers may come to each composition presuming that Pamela and Syrena have expected their own outcomes, and indeed in terms of moral culpability, their narratives conclude as expected: "good" Pamela has her "virtue rewarded" and "bad" Syrena's "feing'd innocence [is] detected" (Haywood, 51). In discussing the cognitive theories and specifically theory of mind, Lisa Zunshine suggests that we (readers) react vigorously or passionately to texts because our minds are tricked into believing that the characters we "encounter" are real and therefore the consequences that we imagine for these imagined people are also very real:

On some level ... works of fiction manage to "cheat" these mechanisms [which process information about human thoughts and feelings] into "believing" that they are in the presence of material that they were "designed" to process, i.e., that they are in the presence of agents endowed with a potential for a rich array of 
intentional stances. Literature pervasively capitalizes on and stimulates ToM [theory of mind] mechanisms that evolved to deal with real people, even as readers remain aware on some level that fictive characters are not real people at all. . The very process of making sense of what we read appears to be grounded in our ability to invest the flimsy verbal constructions that we generously call "characters" with a potential for a variety of thoughts, feelings, and desires, and then to look for the "cues" that allow us to guess at their feelings and thus to predict their actions. (273-274)

According to Zunshine, readers come to texts with the expectation that they will encounter satisfactory resolutions to a plot in which they not only have invested so much time in reading but also possess an ephemeral or intangible relationship with. The public reacted so strongly to Pamela's story because it was implausible that a young woman could be so self-righteous and manage to cross class boundaries with her marriage to Mr. B. Syrena's plot, while still imbued with hyperbole and aspects of the absurd, still managed to punish its protagonist in a real and meaningful way: she was not allowed to escape the consequences for her outlandish and immoral behavior:

Thus was Syrena taken from the first Captivity she had ever been in; but when she consider'd, she was going to a second, which, tho' less shameful, would in all Probability deprive her entirely from all Conversation with Mankind, she was almost inconsolable - Fatal Necessity, however, must be obey'd, and she was sent under the Conduct of an old Servant of one of her Kinsmen to Wales... (227) As such, the reader was more ready to forgive a character who received punishment for actions that were considered illicit. 
Haywood has drawn Syrena as a character for whom the audience understands will be punished at the conclusion of the narrative — as the subtitle indicates, her "feign'd innocence" will be detected. Her raucous behavior is much more forgivable than Pamela's unalterable morality, as Syrena's audience understands the narrative to be both a satire of Pamela and a raunchy jaunt that allows the reader to participate in illicit and yet utterly universal behaviors. Syrena is operating in a theatre that allows her to impose her will upon others: she is a feminized self-author, akin to Locke's man of free will. The loss, then, of Syrena's virginity should be read as a moment that is performed with Syrena fully cognizant and consenting of the act itself. Because the heroine is so distinct from Pamela, one could presume that Haywood would choose to draw her just as hyperbolically cunning, as fully agential and self-determined as Pamela is naïve and enclosed. This, however, is not what occurs in the narrative. Rather, Syrena's first sexual encounter is presented as an occasion where she loses the ability to manipulate or control the desire of her lover, Vardine, and is overwhelmed by his determination to engage in a sexual act. Simply put, she is raped. The scene, similar in scope to Fantomina, is shocking in its portrayal of the male as predatory and unwavering in his lust and distinct from the rest of the narrative in the ways in which Syrena is depicted. For a brief narrative moment, Syrena becomes the victim rather than the manipulator:

The young Officer perceiving the Ground he gain'd, did not fail pursing the Attack, and bombarded her so fast with Speeches out of Plays, tender Pressures, Kisses, and the more intoxicating Juice of the Grape, that at length the Town was wholly his; - - then momentary Rapture over, the Power of Reflection return'd to this unhappy ruin'd Girl—she reproach'd him and herself; —she wept;- - she 
exclaimed; - but it was now too late. He said a good many fond things to her, but he made a jest of her Complaints; why my dear, cry'd he, you desir'd to know the story of Dido and Aeneas, and I have more than told it to you, for I have acted it to the Life. (76)

Syrena's inability to engineer Vardine's behavior is the transformative moment in AntiPamela. Vardine is no less calculating than Syrena. However as a single, European predatory male, his body will always exert power over women. Syrena certainly realizes this point far too late in their encounter, after the "Power of Reflection return'd." Prior to this encounter, Syrena had been indoctrinated by her mother to believe that her beauty and coquettish manner were the only skills that she possessed and that they would help secure a wealthy match for Syrena and thereby also her mother. While this value system does not alter after the loss of her virginity, it does discharge Syrena's seemingly unalterable allegiance to her mother and her mother's opinions. This loss invokes a conscious resolution and constitutive authority within Syrena that sanctions the removal of her mother and the installation of herself as a figure of authority.

One way that Haywood chooses to subtly detail Syrena's intellectual understanding of herself is within Vardine's discussion of Virgil's Aeneid. In the moments before the above scene, Syrena is clearly hesitant to enter a tavern with Vardine, but because of bad weather he insists that they go inside and furthermore recalls the story of Dido and Aeneas' encounter in a cave, an aspect of the poem that is clearly unknown to Syrena as it is mainly concerned with their first sexual encounter. Vardine is appraising Syrena's cultural and sexual intelligence by referencing such an infamous tale; however, Haywood's inclusion of the Dido and Aeneas story is prescient because it is 
also exhibits Vardine's lapse of memory in what occurs following Dido and Aeneas' encounter in the cave. What Vardine chooses to forgo in his re-telling of the story is Dido's fury at Aeneas' abandonment, her suicide on a pyre, and most importantly, her deification by the denizens of Carthage. Dido is not simply the archetypal scorned woman; rather, she becomes a figurehead for women and oppressed minorities who have been pillaged and torn apart by war. For Haywood, war is a metaphor for love and sex, particularly as the act of losing one's virginity is a violent penetration that can never be undone. Both Syrena and Vardine are soldiers in uniform; nonetheless, unlike Vardine's traditional garb ("he be an Officer, as I guess by his Cockade"), Syrena's uniform of war is her exterior beauty, coquettish behavior, and alluring attire ("he all the time entertaining me with Praises of my Beauty, and the Impression it had made on him") (66, 68). As Dido perfectly captures authority, feminine sexuality and grief in material form, she becomes an ideal emblem for women who must capitalize upon their loss lest it immobilize them. Haywood's inclusion of the Dido and Aeneas story is superficially concerned with Vardine's manipulation of Syrena and is meant to underscore her transition from an intellectually naïve girl to a self-authorizing woman, which occurs only after Vardine's assault.

Haywood structures Syrena's progression from feigned ingénue to victim to feigned ingénue extraordinaire within the framework of the dichotomous instructor-pupil relation: Syrena is first her mother's student and then is rendered a neophyte in seduction by Vardine. The shift in Syrena's sexual intelligence that occurs after her assault dramatically alters the ways in which Syrena engages in sexual manipulation. Like Dido's inconsolable fury at Aeneas' departure, Syrena develops a purposeful rage 
directed at Vardine's assault and abandonment of her. For Syrena "Rage did not so far bereave her of her Senses... but as she was capable of loving in reality nothing but herself, and carried on a Correspondence with him merely on a mercenary view...her Management of [Vardine] afterwards shewed the Instructions given her had not been thrown away; and that she had both a Genius and Inclination to make the most of her Men..." (83-84). The text is insistent that this progression from ingénue to agential selfauthor is realized by Syrena's active engagement. While the rape of Syrena is no doubt understood to be both troubling and horrific by modern readers, Haywood insists that this moment should be read as an act of progression: she is meant to acquire a knowledge from Vardine that she could never have mastered from her mother and so the rape and its immediate aftermath becomes the moment, very much like Dido's tale when Aeneas' departure fuels Dido's funeral pyre, when Syrena is empowered and emboldened to superintend her own path.

In 1725 Haywood published Fantomina: or, Love in a Maze, an original story surrounding the ingenious ways in which a young woman disguises herself so as not to be abandoned by her capricious lover. The reader is introduced to Fantomina as a young woman who was "not of a Disposition to consider any Thing very deeply" but whose curiosity is aroused when attending the playhouse for the first time she encounters women "who c[a]me there for no other Purpose than to create Acquaintance with as many as seem desirous of it" (227). Fantomina is distinct from both Pamela and Syrena in that she is neither excessively virtuous nor immoral; rather, she exists within a world wherein she is allowed to construct the boundaries that contain her and rebel as her curiosity dictates. Her virtue is not wholly dependent upon the material condition of her 
virginity, as she has no present and watchful custodian overseeing her body and guiding her conduct. Until the last page and a half of the novel, Fantomina, much more than Syrena, initiates and prescribes the terms that surround the courtship with her unknowing lover, Beauplaisir, and to a greater extent the terms that dictate her sexuality. Haywood begins the narrative by portraying Fantomina as an inexperienced — and uncontainedyoung woman whose first sexual encounter swiftly transforms into her a woman whose material intelligence is linked to the curiosity and activity that surround her sexuality. In "Lying Bodies of the Enlightenment: Theory of Mind and Cultural Historicism" Lisa Zunshine merges the eighteenth-century novel with modern cognitive theory to demonstrate how narratives represent the body "as a site of performance and deceit [which] counterbalanced fictional narratives that portrayed the body as a reliable source of information about a person's mind" (117). Zunshine illustrates the ways in which eighteenth-century narratives discuss and portray human interactions that can be linked to theory of mind, a term used by cognitive theorists to analyze how we "read" people's expressions and then internalize certain meanings from them. Fantomina's seemingly irrational behavior can easily be associated with Zunshine's use and explication of theory of mind, as the heroine seems to instantaneously, and without acknowledging the threat of consequence that might occur, assume the behaviors of "those Women who make sale of their Favors" (227). Zunshine argues that: as paradoxical as it may seem, we treat with caution the information about the person's state of mind inferred from our observation of [their] behavior and body language precisely because we can't help treating them as a highly valuable source of information about [their] mind — and we both know it. Because the body 
is the text that we read throughout our evolution as a social species, we are now struck, for better or for worse, with cognitive adaptions that forcefully focus our attention on that particular text... The desire to revalorize the body as the true source of information about a person's mind must have assumed different forms throughout the [eighteenth-century]. Second...these attempts at stabilizing the meaning of the body must have remained relatively short-lived, unreliable, and open to subversion $(120,121-122)$.

Zunshine accurately points to body as the text from which we read and recognize information. Feminine bodies, even more so than masculine bodies, "forcefully focus our attention" on a sexualized text. These so-called lying bodies are replete with information, and they can alternately be found in the characters of Pamela, Syrena, or Fantomina, as they each respond to other bodies in distinct and compelling ways. In the instance of Fantomina's narrative, she is obliged by an unconscious or unmediated response system - namely, the simplistic state of curiosity — to alter her proscribed behavior. She, in Zunshine's words, transitions from "the role of the spectator...into that of participant" (121) in ways that may have been unimaginable prior to her encounter with the particular set of people on that particular night at the playhouse.

Fantomina, like Syrena, begins the narrative as intellectually aware of sexuality. Her curiosity is proof of that, even if the awareness is an unconscious cognitive response. But she surely does not or cannot comprehend sexuality in action or even fully understand the grave consequences that she may face, and in fact, does encounter in the form of Beauplaisir's many abandonments and the pregnancy that ends her exploits. Like Syrena, Fantomina approaches the transition that will end her virginity with a bold 
assurance that itself can be considered an innate cognitive response. For Fantomina, the innate response is her unabated sexual curiosity: Haywood describes Fantomina with adjectival phrases such as "naturally vain" and seeking "Gratification for an innocent Curiosity" (227). Her mind understands sexuality, and especially penetrative sexuality, as a fundamentally altering experience, so like Pamela and her fainting spells, both Fantomina and Syrena respond to their imminent sexual encounters by blinding pressing forward, oblivious to the consequences that await a young woman who has lost not just her virginity, but also her virtue.

The extenuating loss of Fantomina's virginity is curious in that she is neither driven by greed like Syrena nor hyperbolically protective of her virtue like Pamela. Instead, she is simply interested in the courtesy and attention that other women are receiving from men at the playhouse. Her innate sexuality causes her to act rashly, even dangerously, but it is not until the loss occurs that Fantomina acts in a resolute and determined manner. Prior to the loss, she simply allows Beauplaisir to direct the course of her seduction, only ensuring that she will not be caught. Nevertheless, Haywood draws Fantomina's loss similar to that of Syrena's: she is raped:

- - Shocked, however, at the Apprehension of really losing her Honour, she struggled all she could, and was just going to reveal the whole Secret of her name and Quality, when the Thoughts of the Liberty he had taken with her, and those he still continued to prosecute, prevented her, with representing the Danger of being exposed, and the whole Affair made a Theme for public Ridicule.-Thus much, indeed, she told him, that she was a Virgin, and had assumed this Manner of Behavior only to engage him. But that he little regarded, or if he had, would have 
been far from obliging him to desist...In fine, she was undone; and he gained a Victory, so highly rapturous, that had he known over whom, scarce could he have triumphed more (230).

Fantomina had perfectly performed her embodied mirroring of the playhouse prostitutes, but in the process, she had neglected the very necessary intellectual maneuvers that must be in place in order to survive such perilous endeavors. In other words, she was not cognitively mature enough to understand the consequences that lay in wait when one "plays" adult. Fantomina, very much like Pamela, exists within a plane of abundant sensuality: every action and every body movement is replete with meaning, and the reader must endure a sort of intellectual sensory overload when encountering these narratives. It seems hyperbolic but generically correct to discuss these three women in terms of their sensory systems. Women were very often described as possessing too much sensibility but rarely, if ever, described as having too much intellectual acumen. Zunshine again deftly articulates the notion of "lying bodies" within the context of how we read and correspondingly react to other people's bodies when she argues that too often eighteenth-century texts would rely upon an embodied discourse:

The research on theory of mind thus helps me to make sense of the stubborn overprivileging of body language by eighteenth-century fictional protagonists as well as their readers. Their collective cultural experience (which included fictional narratives) no less than their daily social experience must have taught them to remain wary and to distrust appearances, but experience cannot fully override our cognitive propensity to "trust" the language of the eyes and of the body; it didn't then and it doesn't now. Nor would we really want experience to 
override it, given that people's bodies and facial expressions do speak to our minds and bodies in numerous ways, many of which we are not even aware of ... Because our evolved cognitive repertoire includes adaptations that attribute mental states based on people's body language, we must constantly negotiate a path between our habitual recourse to that language and the realization that the body often deceives (127).

So, if the loss of one's virginity presupposes an intellectual awareness that was not previously present, what does it mean for Fantomina and figures like Mr. B. who read too much into the body language of those around them? The answer can be explained as either a narrative impetus - the force that compels the plot forward—or the curiosity that is inherent when bodies are present and in active discourse with one another. In other words, their initial curiosity is a native embodied intelligence that supports the movement or progression forward into a more articulate intelligence once the veil of virtue is removed.

This native intelligence, however, is not to be confused with the idea of virginity as a disability as was discussed in chapter 3. Rather, I am arguing that the loss of virginity ennobles women who were heretofore nascently aware that their bodies could be perceived as sites of discourse. After the rape has occurred, women like Fantomina and Syrena use their embodied discourse as a way to manufacture authority, all the while acknowledging that their assault has fundamentally altered their cognitive physical selves. This can be seen in Fantomina after her initial curiosity leads to the loss of her virginity, a loss that she verbally decried and physically fought against, but is insistently in command of once she fully comprehends the situation. Fantomina is of course not the 
protagonist's given name; rather, she becomes Fantomina as a way to conceal her true identity. The persona of Fantomina is a manifestation of her inner, sexualized, mature self: “...if he boasted of this Affair, he should not have it in his Power to touch her Character: She therefore said she was the Daughter of a Country Gentleman, who was come to Town to buy Clothes, and that she was called Fantomina" (231). The loss of the protagonist's virginity has created the persona of Fantomina and provides a platform for her to ensure that she is the one who controls Beauplaisir's heart, an action that she surely would not have been incapable of prior to her transformation into Fantomina.

Fantomina's intelligence is not one that can be described as rational; rather, it is an intelligence that is compelled by her emotional state. Haywood details Fantomina's irrational intelligence by writing: "She had Discernment to foresee and avoid all those ills which might attend the Loss of her Reputation, but was wholly blind to those of the Ruin of her Virtue; and having managed her Affairs so as to secure the one, grew perfectly easy with the Remembrance she had forfeited the other" (232). But her irrationality, much like her earlier state of curiosity, allows Fantomina to determinedly set her course and her attentions wholly on Beauplaisir by refusing to accept his abandonment: "Her design was once more to engage him, to hear him sigh, to see him languish, to feel the strenuous Pressures of his eager Arms, to be compelled, to be sweetly forced to what she wished with equal Ardour was what she wanted and what she had formed a Stratagem to obtain, in which she promised herself Success" (234). Her determination is a form of intelligence that exists posteriori: the loss that she experiences transforms Fantomina into one who possesses a resolute, if not irrational, intelligence. 
Finally, to return to Pamela, we must address the gradual loss of her virginity rather then the abrupt losses experienced by both Syrena and Fantomina. While the novel does include a break in Pamela's journal between the period of pre- and post- coitus, her slow and strange transformation from servant to victim to wife is always underscored by the binary of fear and desire. Pamela's intellectual faculties reside in her innate ability to speak the truth, so while Richardson's prose is alive with hyperbolic sentiments, the reader is invited to view Pamela as a child in transition: she does not possess the constructed edifice of elite mannerisms that Mr. B. is accustomed to. He at once views her with disdain for not complying with his cues and also great interest because she is clearly attuned to a different kind of intelligence, one that is best articulated at the point of transition. Pamela's transitory state of intelligence is evident in her age: she is after all only fifteen during the events of the narrative, a mere adolescent; and also, the very unstable state that she exists within while confined to Mr. B.'s estates. Early in the novel she is continuously at a point of returning home but never quite manages to leave; moreover, during her imprisonment in Leicestershire, she remains fearful of her transition from virgin to non-virgin and later as servant to wife.

But as was discussed previously, Pamela's intelligence is always framed by the dual considerations of fear and desire. Fear, for Pamela, resides within the unknown. While she demonstrates curiosity at her irrational interest and desires — such as when she is so determined to "work all Hours with my Needle, upon his Linen, and the Linen of the family; and am besides about flowering him a waistcoat" (22) despite her firm resolution to leave Mr. B. and his estate - she manifestly stamps these notions down whenever temptation lures her. In regards to desire, Pamela is ensconced by a multiplicity of such 
responses: a desire to return home, a desire to please her mistress and then master (which itself can be seen as a transition from desire to please a parental figure to an unspoken sexual desire), and the awareness that she herself is desired. Her desire is often divided between herself and Mr. B. Early in the novel when she is planning to return home, she postpones her trip because she insists upon completing an embroidery project for Mr. B., and Margaret Ann Doody views this scene as a pivotal moment in which Pamela responds cognitively to her desire. But, Pamela's response is pointed inward and not toward Mr. B.:

...she is engaged in the process of making a self. We can be persuaded that we see her growing...When Pamela decides (sadly) that she really must leave B.'s household, she knows the villagers of her parents' parish will make fun of her. She makes herself, at considerable cost to her personal funds and with a good deal of labor, a country costume. She then tries it on, and looks at herself in the glass. Some critics have seen in this episode only an instance of Pamela's vanity and her desire to trap Mr. B. by her masquerading charms. But Pamela seems rather to be acting at herself, for herself. The person she seduces with her country garb is Pamela, so she can turn her back on the fine shoes and the French necklace. Pamela wants to love herself. Richardson presents the not as startling narcissism or reprehensible vanity, but as a natural response of the girl of fifteen. Morality does not exist in some prim, airtight box. We live out moralities in our experience: our sense of right harmonizes with our sense of ourselves. (103) Doody correctly articulates a Pamela-in-transition. Richardson's text could not have concluded with the joyous union of Mr. B. and Pamela if Pamela herself was not fully 
able to transition from child/servant to a woman whose intellectual empathy outweighed and even altered those around her, namely Mr. B. himself. The curiosity or initial movement toward sexuality compels Pamela, Syrena and Fantomina away from their compulsory concealments and toward an functioning and self-authored intelligence. Each of these moments in their respective narratives represent a movement away from guardianship and a transition to a liberation that was heretofore unknown.

Early in the novel, Pamela's ability to incite Mr. B.'s interest is superficially tied to her beauty, but it also should be linked to her innate faculty to speak truth to Mr. B. Carine Harol identifies this trait as a lack of artifice and argues that:

One of the defining features of virtue is the lack of artifice; Pamela cannot be deliberately deceptive. Therefore, she must scrutinize her own feelings and own up to them, a task that takes up a good deal of Pamela's journal writing. Interestingly, as virtue comes to reside in her intangible interiority instead of her body, Pamela is increasingly subject to confusion and self-deception. (139) Her confusion surely lies within the necessary bewilderment that accompanies adolescence and its progression into the transitory state between child and adult. For Pamela, there is no safer place to be than in her letters home and later in her journal. Her words act as a bulwark to the continuous onslaught that Mr. B. perpetuates against her body. Nevertheless, Pamela is forcibly transferred to Mr. B.'s Leicestershire estate, and it is here, in this moment within the narrative, that the crucial transition occurs. The action of removing Pamela from Mr. B.'s Bedfordshire estate to his more secluded and private estate in Leicestershire that is the penetrative, disruptive action. The transition itself is one that propels Pamela forward: whereas in Bedfordshire she was a naïve servant girl 
who refuses all of Mr. B.'s advances; in the other estate, her violent transfer commences a point within the narrative in which she becomes his paramour and wife. Moreover, the relocation can be read as a metaphor for the sexual act itself, as the coach penetrates deeper into the interior of the countryside and further away from the eyes of Pamela's family and friends.

Pamela, like Syrena and Fantomina, is raped by her captor in that she was not given a choice regarding the state of her virginity. While the condition of her virginity is lawfully intact on the day of her marriage, Mr. B. assaulted and forcibly relocated her with the express intention of engaging in a sexual act with Pamela. But, like Fantomina and Syrena, the moments before and after the transition occurs, Pamela's ability to conceive of herself as a subject rather than an object merits attention because it also is the point within the narrative the Pamela is able to reorient Mr. B. from a scoundrel to a loving spouse. While Richardson's attempt to moralize Mr. B. and soften Pamela's determined morality are magnified and embellished, he does allow Pamela space in which she can, for a small period of time, intellectualize her moment of transition.

The loss of virginity, then, can be read as a moment that provides agential selfauthority in these novels. Pamela, Syrena, and Fantomina each represent a curious moment when narratives were highly concerned with the ways in which bodies elicited cognitive responses. Put simply, Pamela's beauty was the impetus for Mr. B.'s enrapture and confinement of her, Syrena was blinded by her lust for money and Vardine, and Fantomina was overwhelmed by her sexual curiosity. However simplistic these descriptions are, the intelligence that was garnered by each of these characters remain 
important moments in their respective narratives as these instances compelled Pamela, Syrena, and Fantomina toward a level of intelligence that they previously did not possess. 


\section{REFERENCES}

Barker-Benfield, G.J. Culture of Sensibility: Sex and Society in Eighteenth Century Britain. Chicago: University of Chicago Press, 1996. Print.

Bellamy, Liz. Commerce, Morality and The Eighteenth-century Novel. Cambridge: Cambridge University Press, 1998. Print.

Butler, Judith. Bodies That Matter: On the Discursive Limits of Sex. New York: Routledge, 1993. Print.

---. Gender Trouble. New York: Routledge, 2006. Print

---. Excitable Speech: A Politics of the Performative. New York: Routledge, 1997. Print.

Derrida, Jacques. Limited Inc. Vol. 10. Evanston: Northwestern University Press, 1977. Print.

Goodey, C.F. A History of Intelligence and "Intellectual Disability”: The Shaping of Psychology in Early Modern Europe. Burlington: Ashgate, 2011. Print.

Grosz, Elizabeth. Volatile Bodies. Bloomington: Indiana University Press, 1994. Print.

Gwilliam, Tassie. Samuel Richardson's fictions of Gender. Redwood City: Stanford University Press, 1995, Print.

Harol, Corrine. Enlightened Virginity in Eighteenth Century Literature. New York: Palgrave Macmillan, 2006. Print.

Harvey, A. D. "Clarissa and the Puritan Tradition." Essays in Criticism (1978) XXVIII (1): 38-51.

Haywood. Eliza. “Anti-Pamela; Or, Feign'd Innocence Detected.” Haywood, Eliza. AntiPamela and Shamela. Ed. Catherine Ingrassia. Ontario: Broadview Press, 2004. 51-227. Print.

Haywood, Eliza. "Fantomina: Or, Love in a Maze." Eds. Paula R. Backscheider \& John J.Richetti. Popular Fiction By Women, 1660-1730: An Anthology. Oxford: Oxford University Press, 1996. 227-248. Print. 
Ingrassia, Catherine. Anti-Pamela and Shamela. Peterborough: Broadview Press, 2004. Print.

Locke, John. An Essay Concerning Human Understanding. Oregon State University. Web. December 14, 2014.

---. An Essay Concerning Human Understanding: Abridged And Edited, With An Introduction And Notes. Indianapolis, Ind.: Hackett Pub. Co., 1996. Print.

Morse, David. The Age Of Virtue: British Culture From The Restoration To Romanticism. New York: Palgrave Macmillan, 2000. Print.

Richardson, Samuel. Pamela, Or, Virtue Rewarded. Ed. Thomas Keymer and Alice Wakely. Oxford: Oxford University Press, 2008. Print.

---. Pamela, Or, Virtue Rewarded. Ed. Peter Sabor. London, England: Penguin Books, 2003. Print.

"Tabula, n." OED Online. Oxford University Press, December 2015. Web.

Watt, Ian. Rise of the Novel: Studies in Defoe, Richardson and Fielding. Oakland: University of California Press, 2001. Print.

Wollstonecraft, Elizabeth. Vindication of the Rights of Women. New York: Dover Publications, 1996. Print.

Zunshine, Lisa, ed. Introduction to Cognitive Studies. Baltimore: Johns Hopkins University Press, 2010. Print.

---. Approaches to Teaching the Novels of Samuel Richardson. New York: MLA, 2006. Print. 